Article

\title{
Generational Changes in Agriculture: The Influence of Farm Characteristics and Socio-Economic Factors
}

\author{
Wojciech Sroka ${ }^{1, *(\mathbb{D})}$, Michał Dudek ${ }^{2} \mathbb{( D )}$, Tomasz Wojewodzic ${ }^{1}$ and Karol Król ${ }^{3}[$ \\ 1 Department of Economics and Food Economy, University of Agriculture in Krakow, Al. Mickiewicza 21, \\ 31-120 Kraków, Poland; tomasz.wojewodzic@urk.edu.pl \\ 2 The Institute of Agricultural and Food Economics-National Research Institute (IAFE-NRI), ul. \\ Świętokrzyska 20, 00-002 Warszawa, Poland; michal.dudek@ierigz.waw.pl \\ 3 Department of Land Management and Landscape Architecture, University of Agriculture in Krakow, Balicka \\ 253c, 30-149 Kraków, Poland; k.krol@onet.com.pl \\ * Correspondence: w.sroka@ur.krakow.pl
}

Received: 20 November 2019; Accepted: 12 December 2019; Published: 15 December 2019

\begin{abstract}
The increasing importance of large cities (metropolises) poses a range of challenges to the socio-economic functions of the rural and agricultural areas around them. One such challenge is pressure exerted on family-run farms to abandon agricultural activity and on people engaged in such activity to shift to other sectors. This may be a hindrance to successful succession on family farms. The aim of this paper is to present spatial variation in generational changes in farms located around large cities (metropolises) in Poland and to assess the factors affecting the scale of such changes. Special attention was paid to the importance of the location of farms relative to large cities. One innovative feature of the approach presented was to conduct an analysis of generational changes in the agricultural sector at the supra-local level along with an attempt to quantify the impact of large urban centers on that process. The empirical material based on which the conclusions were formulated included official statistics data and information made available by an institution engaged in the implementation of agricultural policy programs financed from European Union (EU) funds, i.e., young farmer payments (Common Agricultural Policy (CAP) pillar I) and measures "Setting up of young farmers" and "Early retirement" (CAP Pillar II). In the executed study, methods of descriptive and multivariate statistics, including regression trees, were used. It was found that socio-economic (exogenous) factors had a significant statistical impact on generational changes in farms. In areas with an attractive labor market and a high level of urbanization, a successful generational shift in farms occurred less often. Nonetheless, generational changes in the agriculture of the analyzed areas were relatively most strongly determined by endogenous factors linked with the economic potential of the farm. Farm characteristics (area of agricultural land and economic size) and the characteristics of managers, including in particular their education, were found to be more important than exogenous factors. In areas where large and economically strong farms dominated and the level of education among farmers was relatively high, generational changes were faster compared to other areas.
\end{abstract}

Keywords: generational changes; agriculture; succession; young farmer; early retirement; metropolitan area

\section{Introduction}

In public and expert debate, it is increasingly stressed that the development of agriculture in cities and around them brings a range of economic, environmental and social benefits. Urban and peri-urban agriculture (UPA) contributes, among other things, to the strengthening of local food production, preservation of the landscape, and biological diversity, as well as creating recreation and leisure sites, 
etc. [1-4]. However, the development of UPA, thus contributing to the preservation of the viability of rural and urban areas, requires generational renewal in family farms [5,6]. In the classical model of farm succession, farm managers in the final years of their working age were replaced by successors, usually family members willing to take over the ownership and managerial control of the business assets [7]. As a result of economic, social, and cultural progress, the traditional ways of farming and succession are evolving, with the present socio-economic conditions in Poland and other European countries making it more difficult for young people to enter the agricultural sector [8,9]. Particularly serious problems may occur in the agriculture of highly urbanized areas, where an attractive labor market and relative deficit of land limit the possibilities of the development of agricultural farms, thus decreasing the probability of successful succession $[5,10]$.

With the growing global demand for food, the desire to maintain the competitiveness of European agriculture and challenges related to the state of the environment and climate change, the demographic problem of agriculture has become an important issue in the EU common agricultural policy (CAP). Consequently, instruments to support generational changes in farming families have been implemented [11,12]. However, the effects of the interventions so far have been criticized due to their limited effectiveness [13]. Also, studies conducted in Poland indicate very dynamic structural/generational changes in the agriculture of urban and peri-urban/metropolitan areas, including an increase in processes of exiting from farming $[14,15]$. However, the scale and spatial variation in generational changes in agriculture, not to mention their drivers, are not known.

The issue of generational changes in agriculture in metropolitan/peri-urban areas is one which has been addressed relatively rarely [16]. Similarly, the impact of exogenous factors, including socio-economic ones (especially in urbanized areas), on structural changes in the agricultural sector has not been analyzed very extensively $[17,18]$. This paper is an attempt to fill this gap. Its aim is to present the spatial variation and identify and assess the factors affecting the pace of generational changes in farms located around large cities. In doing so, special attention was paid to the importance of the location of farms relative to large cities in terms of the processes of generational changes.

The text consists of five parts. The next chapter presents a review of the literature on generational changes in agriculture being influenced by cities. Further, data sources and applied methodology are discussed. It is followed by a presentation of research findings. The paper ends with a discussion and conclusions.

\section{Theoretical Background: Generational Changes and Their Drivers in Peri-Urban/Metropolitan Agriculture}

The issue of generational changes in agriculture has an increasingly important place in the economic and agricultural literature [16,19-21]. This is due to the great social, economic, environmental, and political significance of family farming. The critical importance of the persistence of this organizational form of agricultural production is connected with its role in preserving the viability of rural areas, livelihood of large groups of population, food security, and the state of the environment, which is reflected in the agricultural policies of the different EU countries [22]. Despite unfavorable demographic and economic phenomena, family-run farms, thanks to a well-developed mechanism of succession, show a relatively strong level of resilience [23,24]. Therefore, a lot of studies conducted so far have focused on identifying the conditions of the process of intergenerational transfer of family farms. These studies usually used a microeconomic approach (were conducted at the level of a farming family) and attributed successful intra-family farm transfers to the impact of a range of characteristics of the farm (economic size, level of production specialization, production profile), the farm manager (age, sex, level of education, off-farm job), the farm manager's spouse (age, sex, involvement in the work on the farm), and the successor (age, sex, level of education, professional experience) $[25,26]$. Such analyses estimated the chances of ex-ante succession, as declared (or, to a lesser extent, actual) in families, mainly based on the logit model [27,28]. A relatively less significant number of studies have addressed the impact of exogenous factors on farm succession (present in the environment of the 
family and the farm; economic, social, environmental, and agro-climatic factors) at a local, supra-local, regional, or national level $[17,18]$.

The literature on determinants of family farm succession indicates that three main groups of factors are important, namely farm, farmer, and farm household characteristics [29,30]. Moreover, it is pointed out that an important role is played by exogenous factors, including environmental and location factors [16]. These factors include the interplay between farm and territorial factors (rural-urban relationships) [29]. However, the location factor is not perceived in a classic way, i.e., in terms of the distance from the market, but rather as a set of socio-economic conditions that impact the existence of benefits and costs connected with conducting agricultural activity at a given location [16,31]. The advantages/disadvantages of location are a product of the effects of agglomeration and urbanization, as well as environmental conditions or even historical and cultural factors. These effects are very rarely analyzed in the research literature, but a few significant publications clearly emphasize that the local conditions of the labor market and processes of urbanization have a huge impact on farm succession $[29,30,32]$.

Processes of urbanization (and metropolization) involve deep transformations of rural areas. According to theory and research in the area of regional and local development, economic development, which is the result of innovative activities and the functioning of high value-added industries, tends to be concentrated in large urban (metropolitan) centers and their functional areas [33]. With economic development, there is increasing settlement in areas impacted by the labor markets of the economic core [34]. As a result of construction, as well as residential and infrastructure investments, cities sprawl, encroaching upon and converting agricultural areas, often of high environmental value, in the process [35].

However, the impact of processes of urbanization and metropolization on generational changes in agriculture varies. On the one hand, the proximity of large urban centers with an attractive labor market does not facilitate the transfer of farms to younger family members, who rather tend to choose to work in non-agricultural industries where they are likely to be offered higher salaries $[10,14,36]$. Moreover, opportunities for the development of farms are limited by a large demand for land from the non-agricultural sector (for the purposes of residential construction, development of social and technical infrastructure) as a result of an increased population density and by speculation by landowners $[14,37,38]$. Consequently, the number of potential successors is likely to be smaller. On the other hand, the proximity of a metropolis may provide a chance for the development of multifunctional agriculture [39]. Numerous examples of agricultural farms both in Poland and other countries show that urban and peri-urban areas are suitable for development of: local food farms, leisure farms, social farms, and many other multifunctional facilities [16,18,40-42]. The research literature emphasizes that the key to succession is choosing the right adjustment strategy that will facilitate economic success and farm succession $[14,43]$.

\section{Research Methodology}

\subsection{Data Sources}

In the manuscript, a few sources of information and data have been used. One of the sources was research conducted by other authors (the research literature). The literature review was carried out in the first half of 2019. It involved seeking useful keywords and assessing the exploration of the issue of generational changes/farm succession in agriculture studies. The collected material (based on analysis of abstracts) was subjected to selection: the most recent analyses carried out in Europe and covering peri-urban/metropolitan areas (MA) were prioritized. Part of the literature was regional (e.g., publications in the Polish language) due to the character of the studies and the necessity of referring to specific factors in the development of Polish agriculture.

Main source of empirical material was the data from the local data bank of the Statistics Poland (LDB Poland) and the unique (primary) information provided by the agency for restructuring and 
modernization of agriculture (ARMA) upon submission of a request for access to public information. The data obtained from LDB Poland - the largest database of the economy, society, and the environment in Poland, managed by the Statistics Poland-pertained to the socio-economic situation in the areas studied and included information gathered during agricultural censuses (on the characteristics of agricultural farms). The information received from ARMA illustrates farmers' interest in securing EU funds for generational changes in agriculture. ARMA is a government institution, designated to perform the role of an accredited paying agency in Poland, responsible for implementing instruments co-financed from the EU budget. It also holds information about the number of agricultural farms, their structure, etc. The details concerning the variables used in the analyses, including their temporal scope, are presented in Section 3.3.

\subsection{Study Area}

Poland is a country located in Central and Eastern Europe with a relatively huge share of agricultural land (agricultural area accounts for almost $60 \%$ of the country's area). The studies so far undertaken indicate that there are huge regional differences in Poland in terms of farm succession, which are attributed to different economic (including structural) and environmental factors $[6,44]$. Particularly significant structural changes connected with exiting from farming have occurred and are still occurring in highly urbanized areas [45], including metropolitan areas, where the large chances of finding an off-farm job make it easier to decide to leave the agricultural sector.

This paper analyses generational changes in farms located in and around six Polish metropolitan areas: Warsaw, Krakow, Wroclaw, Poznan, the Tricity, and Lublin [45]. It should be noted at this point that in Poland, due to its complicated history (loss of independence in the 18th century and division of the country into three zones of occupation, the consequences of WWII, etc.), there are still huge differences in the level of socio-economic development, including in the development of agriculture [46]. Therefore, the assumption was to select metropolitan areas representing different parts of the country to show their considerable structural variety.

In Poland, metropolitan areas are defined in different ways [33]. In thisresearch, the definition proposed in the national spatial management concept 2030 [47] was adopted, according to which, a metropolitan area is an area of a large city (over 300 thousand residents) and its functionally linked immediate environment as established in the national spatial management concept. Although in Poland, metropolitan areas are distinguished at the level of a municipality (NUTS-5), in this manuscript, due to the way in which data on generational changes (only available at NUTS-4 level) in agriculture was gathered, it was necessary to present an alternative delimitation of metropolitan areas. Thus, based on the borders of MAs delimited at the level of a municipality, i.e., NUTS-5 [45], two groups of poviats (a poviat is the second-level unit of local government and administration in Poland, equivalent to a county, district, or prefecture; LAU-1, formerly NUTS-4) constituting a metropolitan area were distinguished (Figure 1). The first group comprises poviats bordering the city core of the MA (BCCMA), where all the municipalities are part of the metropolitan area. The second group includes poviatstotally or partially located in the MA (ToPMA). Such areas lie, for the most part (almost 80\%), within the administrative borders of the municipalities that are part of metropolitan areas. The third group of poviats is located outside the MA (OMA) and serves as the comparative material. These are poviats with a predominance of rural municipalities without large cities (over 300 thousand inhabitants). 


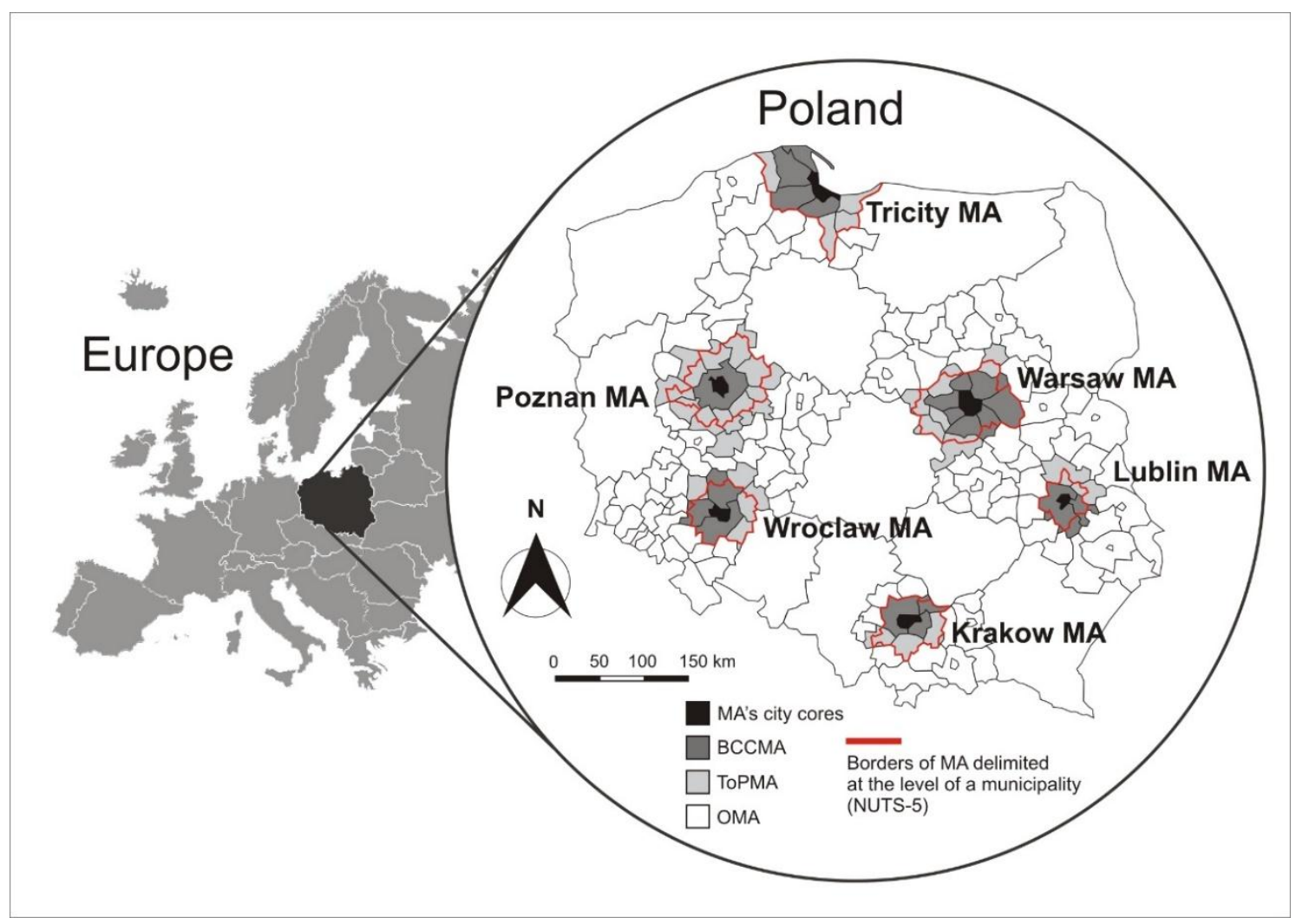

Figure 1. Metropolitan areas falling within the scope of the study. Source: own elaboration.

The aim of dividing the areas studied into three groups is to determine the impact of large urban centers (MA cores) and, as a consequence, to assess the importance of the location factor in the pace of generational changes in agriculture.

The farms located in the BCCMA zone operate relatively close to the cores of metropolitan areas and should be regarded as those most affected by the pressure of urbanization. Indeed, such areas are characterized by a relatively high population density, high net migration, relatively high salary, etc. (Table 1). These indicators differ significantly compared to the other identified groups.

Table 1. Socio-economic characteristics of the areas where the analyzed farms are located.

\begin{tabular}{|c|c|c|c|c|c|}
\hline \multirow{2}{*}{ Specification } & \multicolumn{3}{|c|}{ Areas Studied } & \multirow{2}{*}{ MA's City Cores * } & \multirow{2}{*}{ Poland Overall ** } \\
\hline & ВССМА & ToPMA & OMA & & \\
\hline $\begin{array}{l}\text { Net migration per } 10,000 \text { population-average } \\
\text { for } 2007-2017 \text { (person) }\end{array}$ & 237.6 & 19.9 & -35.2 & 10.5 & 0.17 \\
\hline $\begin{array}{l}\text { Average population density for the period } \\
\text { 2007-2017; (inhabitants } / \mathrm{km}^{2} \text { ) }\end{array}$ & 192.6 & 112.3 & 90.9 & 2474.7 & 122.7 \\
\hline $\begin{array}{l}\text { Share of built-up areas in the total } \\
\text { area-average for } 2012-2014(\%)\end{array}$ & 8.0 & 5.2 & 4.3 & 46.0 & 5.3 \\
\hline $\begin{array}{l}\text { Average monthly gross salary in the years } \\
2007-2017 \text { (Euro } * * *)\end{array}$ & 3400 & 3254 & 3049 & 4209 & 3726 \\
\hline $\begin{array}{l}\text { Economic entities including natural } \\
\text { persons-average for 2007-2017 (entities/10 } \\
\text { thousand population) }\end{array}$ & 1128 & 949 & 791 & 1843 & 1039 \\
\hline Unemployment rate in the years 2007-2017 (\%) & 9.0 & 11.5 & 14.5 & 4.8 & 10.9 \\
\hline
\end{tabular}

${ }^{*}$ The data relate to the city cores of six metropolitan areas studied; ${ }^{* *}$ data refers to the whole country, and in the case of the analyzed MAs and their environment, MA cores and cities with poviat rights have been included; $* * * 1$ Euro was taken to $=4.3$ PLN. Source: own elaboration based on: BDL and ARMA.

The farms located in the ToPMA zone carry on agricultural activity further away from MA cores, but these areas can also see a relatively strong pressure of urban centers on agriculture. The relatively well-developed labor market (low unemployment rate, large number of enterprises), as well as the 
relatively high population density and positive net migration may impact changes in agriculture, including generational changes. The level of socio-economic development in that zone (ToPMA) is comparable to the overall level for Poland.

Farms located outside the MA (OMA) are only scarcely affected by the pressure of urban centers. The socio-economic situation in that zone, especially in terms of the labor market, is considerably worse than average in the country and typical of rural municipalities in Poland.

\subsection{Selection of Variables}

\subsubsection{Dependent Variables—Pace of Generational Changes}

Generational changes in agriculture are an objective process-they occur whether or not they are supported by public funds. However, due to a lack of up-to-date data on farm succession, the data gathered in connection with the implementation of the CAP was used. This data pertains to active farmers, i.e., the group that is most important in terms of the development of the agricultural sector. This paper aims to measure the pace of generational changes in agricultural farms in two ways: (1) by estimating the share of young farmers running agricultural activity, and (2) by determining the level of interest in supporting the generation renewal in agriculture.

As part of the first approach (indicator I-1), we analyzed the share of farmers who received young farmers' payments (component of CAP Pillar I). This indicator reflects the real effects of generational changes (actual ex-post generational changes), as it shows the share of farmers who started agricultural activity within the last 5 years and are under 40 years of age (Table 2). As no additional criteria needs to be met in order to receive young farmers' payments, all active young farmers likely receive such funds [48]. A high proportion of farmers who receive direct payments along with the young farmer payment component means that over the last 5 years there have been dynamic processes of generation renewal in a given area. A weakness of this measure of generational changes is that it does not take into account young farmers with more years worked in agriculture (over 5 years), as this group of farmers is not eligible for this payment.

Table 2. Characteristics of the dependent variables and correlations between them.

\begin{tabular}{|c|c|c|c|c|c|}
\hline \multirow{2}{*}{ The Number of Beneficiaries in the Study Area } & \multicolumn{2}{|c|}{ Values of the Characteristics } & \multicolumn{3}{|c|}{ Correlation Coefficient } \\
\hline & Mean & Coefficient of Variation (\%) & I-1 & $\mathrm{I}-2$ & I-3 \\
\hline $\begin{array}{l}\text { I-1-Number of beneficiaries of the "Young Farmer } \\
\text { Payment" per } 1000 \text { farms benefiting from direct } \\
\text { payments (average for 2015-2017) (Young } \\
\text { farmer-CAP Pillar I) }\end{array}$ & 9.1 & 23.9 & 1.00 & - & - \\
\hline $\begin{array}{l}\text { I-2-Number of beneficiaries of the“Setting up of } \\
\text { young farmers" grantsper } 1000 \text { farms benefiting } \\
\text { from direct payments (average for 2007-2017) } \\
\text { (Young farmer-CAP Pillar II) }\end{array}$ & 3.9 & 74.2 & $0.82 *$ & 1.00 & - \\
\hline $\begin{array}{l}\text { I-3-Number of beneficiaries of "Early retirement" } \\
\text { grant per } 1000 \text { beneficiaries of direct payments } \\
\text { (average for 2007-2010) (Early retirement-CAP } \\
\text { Pillar II) }\end{array}$ & 14.5 & 50.3 & 0.53 * & $0.72 *$ & 1.00 \\
\hline
\end{tabular}

As part of the second approach, farmers' interest in securing funds for supporting generational changes was evaluated. Two indicators were analyzed: I-2: Share of farmers who between 2007 and 2017 received a start-up grant for young farmers (CAP Pillar II), and I-3: Share of farmers who benefited from the "early retirement" initiative. Both these measures show the level of farmers' interest in securing funds to accelerate generational changes.

The "setting up of young farmers" measure (indicator I-2) was directed at farmers who meet a range of criteria (Regulation (EU) No. 1307/2013 of the European Parliament and of the council of 17 December 2013): they are starting agricultural activity, have the required qualifications, and are under 40 years of age. The size of farms taken over by young farmers (the larger the better) 
and the type of planned investments (the higher the increase in value added the better) was also of importance.Thus, a large number of beneficiaries in a given area will reflect fast generational changes and, more importantly, is something which should lead to the improvement of the economic situation of farms, as these funds were received by the best farmers [49].

The last variable (I-3) shows the number of farmers who, in exchange for receiving early retirement (paid to a farmer aged over 55 for a period of up to 10 years), passed on their agricultural farm to their successor. This measure was implemented as part of the 2004-2006 and 2007-2013 rural development programs (Regulation (EU) No. 1257/1999 of the European parliament and of the council of 17 May 1999). Its aim was to improve agricultural structures and accelerate the process of generational renewal among those running agricultural farms, as well as to improve the viability and competitiveness of farms. The criteria for receiving early retirement have changed many times [50], but in principle, once the formal criteria (such as age, farm work experience, transfer of the farm) were met, those transferring larger agricultural farms and those transferring farms to younger farmers (under 40 years of age) were more likely to receive early retirement. Also, in this case, a greater value of the indicator shows a higher pace of generational changes in agriculture.

With all the indicators, there is a relatively high variation measured by coefficient of variation. The analyzed programs were similar in terms of their aims, and to some extent, also the conditions that the potential beneficiaries had to meet (e.g., the access criteria preferred larger farms), therefore they are positively correlated-this is the case with, for example, the variables I- 2 and I-3. There is also a strong positive correlation between variable I- 1 and variable I-2, i.e., the actions directed at young farmers (the first concerns pillar I and the second concerns CAP Pillar II), due to the character of these operations. The farmers who received aid for young farmers under CAP Pillar II also meet the conditions set for beneficiaries of young farmer payments (CAP Pillar I).

Although the analyzed variables are relatively highly correlated, they will be analyzed separately. This is because they differ slightly in character (I-1 refers to real generational changes, while I-2 and I-3 refer to the level of interest in securing funds for generational changes), and their spatial variation and causes of that variation may differ.

\subsubsection{Independent Variables}

Seeking to answer the question of what factors have the biggest impact on farms' interest in securing funds to support generational changes, thirteen independent variables were identified based on the literature review, available statistical data, and expert analysis. They were grouped into four main groups: socio-economic factors, farm structures and viability, natural environmental features, and location (Table 3). The first group is socio-economic factors, and the analyses took into account variables that reflect the attractiveness of the local labor market (salary, unemployment rate, entrepreneurship) and may have an impact on the processes of farm succession [10]. The aim of the research was also to assess the impact of population density, the share of built-up and urbanized areas, and net migration. These factors determine, among other things, availability of land (competition for land) and its prices. Of considerable importance was also the occurrence of the phenomenon of rent seeking and increasing speculation, which "freeze" the agricultural land market [37,45]. 
Table 3. A set of predictors (independent variables) used in the process of modelling.

\begin{tabular}{|c|c|c|c|c|}
\hline Factors & Name of Variable & Definition of Variable and Unit & $\begin{array}{c}\text { Range of } \\
\text { Variation/Size in the } \\
\text { Study Area }\end{array}$ & Source \\
\hline \multirow{6}{*}{$\begin{array}{l}\text { Socio-economic } \\
\text { factors }\end{array}$} & Salary & $\begin{array}{l}\text { Average monthly gross salary in } \\
\left.\text { the years 2007-2017 (Euro }{ }^{*}\right)\end{array}$ & $\begin{array}{c}\mathrm{AV}=729.4 \\
\mathrm{Min}=542.2 \\
\operatorname{Max}=1484.9\end{array}$ & LDB Poland \\
\hline & Unemployment rate & $\begin{array}{l}\text { Average unemployment rate in } \\
\text { the years 2007-2017 (\%) }\end{array}$ & $\begin{array}{l}\mathrm{AV}=13.2 \\
\operatorname{Min}=3.2 \\
\operatorname{Max}=33.5\end{array}$ & LDB Poland \\
\hline & Entrepreneurship & $\begin{array}{l}\text { Economic entities including } \\
\text { natural persons-average for } \\
2007-2017 \text { (entities/10 thousand } \\
\text { population) }\end{array}$ & $\begin{array}{c}\mathrm{AV}=867.2 \\
\operatorname{Min}=434.0 \\
\operatorname{Max}=1635.5\end{array}$ & LDB Poland \\
\hline & Net migration & $\begin{array}{l}\text { Net migration per } 10,000 \\
\text { population-average for } \\
2007-2017 \text { (person) }\end{array}$ & $\begin{array}{c}\mathrm{AV}=12.2 \\
\operatorname{Min}=-156.6 \\
\operatorname{Max}=571.0\end{array}$ & LDB Poland \\
\hline & Population density & $\begin{array}{l}\text { Population density-average for } \\
\text { 2007-2017; (inhabitants/km2) }\end{array}$ & $\begin{array}{c}\mathrm{AV}=108.8 \\
\mathrm{Min}=31.4 \\
\operatorname{Max}=644.1\end{array}$ & LDB Poland \\
\hline & $\begin{array}{l}\text { Built-up and urbanized } \\
\text { areas }\end{array}$ & $\begin{array}{l}\text { Share of built-up areas in the } \\
\text { total area-average for } \\
2012-2014)(\%)\end{array}$ & $\begin{array}{r}\mathrm{AV}=5.0 \\
\operatorname{Min}=2.2 \\
\operatorname{Max}=23.9\end{array}$ & LDB Poland \\
\hline \multirow{5}{*}{$\begin{array}{l}\text { Farm structures and } \\
\text { viability }\end{array}$} & Farm size & $\begin{array}{l}\text { Average size of an agricultural } \\
\text { farm receiving area payment in } \\
\text { the years 2004-2006. (ha) }\end{array}$ & $\begin{array}{l}\mathrm{AV}=11.5 \\
\operatorname{Min}=2.4 \\
\operatorname{Max}=34.7\end{array}$ & ARMA \\
\hline & Young farm employees & $\begin{array}{l}\text { Share of people aged } 15-34 \\
\text { among those working on farms } \\
\text { in } 2010(\%)\end{array}$ & $\begin{array}{l}\mathrm{AV}=30.7 \\
\operatorname{Min}=22.4 \\
\operatorname{Max}=38.5\end{array}$ & LDB Poland \\
\hline & Economically strong farms & $\begin{array}{l}\text { Share of farms with an economic } \\
\text { size in excess of } € 15,000 \text { of } \\
\text { Standard Output-2010 (\%) }\end{array}$ & $\begin{array}{c}\mathrm{AV}=46.8 \\
\mathrm{Min}=3.0 \\
\operatorname{Max}=77.8\end{array}$ & LDB Poland \\
\hline & Part-time farmer & $\begin{array}{l}\text { Share of farm users making a } \\
\text { living mainly from an off-farm } \\
\text { job in } 2002(\%)\end{array}$ & $\begin{array}{l}\mathrm{AV}=33.8 \\
\operatorname{Min}=17.4 \\
\operatorname{Max}=60.5\end{array}$ & LDB Poland \\
\hline & Education & $\begin{array}{l}\text { Share of farmers with at least } \\
\text { medium-level agricultural } \\
\text { education in } 2002(\%)\end{array}$ & $\begin{array}{c}\mathrm{AV}=7.9 \\
\operatorname{Min}=0.5 \\
\operatorname{Max}=20.9\end{array}$ & LDB Poland \\
\hline $\begin{array}{c}\text { Natural } \\
\text { environmental } \\
\text { features }\end{array}$ & Natural conditions & $\begin{array}{l}\text { Soil conditions, agro-climate, } \\
\text { relief and water conditions } \\
\text { calculated on the basis of the } \\
\text { Agricultural Production Space } \\
\text { Valuation Ratio (APSVR) } \\
\text { (points) }\end{array}$ & $\begin{array}{c}\mathrm{AV}=67.1 \\
\mathrm{Min}=33.0 \\
\operatorname{Max}=100.0\end{array}$ & [51] \\
\hline Location & Location & $\begin{array}{l}\text { (dummy variable: BCCMA, } \\
\text { ToPMA, OMA) }\end{array}$ & $\begin{array}{l}\text {-BCCMA-20 poviats } \\
\text { ToPMA-29 poviats } \\
\text { OMA-100 poviats }\end{array}$ & Own elaboration \\
\hline
\end{tabular}

* 1 Euro was taken to $=4.3$ PLN. Source: own elaboration.

The farm structures and viability group includes variables related to the physical and economic dimension of a farm (farm size and economically strong farms) and shows the development potential of farms and their capacity of generating high incomes [52]. We wanted to find out whether in economically and physically larger farms, successful generation renewal occurs more frequently. In addition to that, we tested such variables as: part-time farming, education, and young farm employees, because other studies found that part-time farming combined with off-farm work by operators and spouses generally provides worse perspectives for intra-family succession [53]. The young farm employees variable illustrates the share of young people, including farmers' children, i.e., potential successors, working on farms. Thus, a bigger share of young farm employees should be conducive to farm succession [16]. The last variable in this group, "education", shows the level of education among farm managers. The findings presented in the literature are not clear-cut, as some scholars claim that the probability of succession increases with the parents' level of education [54], 
while others maintain that it decreases [29]. Therefore, we would like to contribute to the literature with our own findings.

The paper also analyses the impact of environmental factors on farm succession. Higher productivity of agricultural land results in higher economic rent from every unit of surface area, which means higher profitability of farms [55], which in turn increases the likelihood of succession.

For modelling, one qualitative characteristic was selected and it illustrates the location of a farms relative to the core of the metropolitan area (see the section entitled 'study area'). We want to find out whether location (proximity) relative to the core of MA will impact the processes of generational changes in agriculture.

The temporal scope of the different variables was limited by data availability, but for the variables from the socio-economic factors group, the average for the 2007-2017 period was used. In the case of the variables from the "farm structures and viability" group, there are numerous types of feedback with dependent variables (e.g., farm transfer in 2007 as part of early retirement leads, as a rule, to an increase in the average size of farms in 2008 - consequently, the high average area of farms in 2008 is both the cause and effect of the 2009 generational changes), therefore, where possible, the initial values, i.e., before 2007 (before generational changes), were used for this group of variables. The variable reflecting the quality of agricultural production space was adopted based on the research conducted in the early 1990s (lack of more up-to-date research), but the environmental conditions of agricultural production are relatively stable [51].

The variables selected for analysis are characterized by a relatively large variation, but not all of them have a normal distribution. Therefore, for modelling the processes of generational changes, a nonparametric method, was chosen-the method of regression trees, the use of which does not require such strict conditions as classical regression models do.

\subsection{Data Analysis: Regressions Trees}

Classification trees are an investigative method for analyzing data. This manuscript employs a method founded on the CART (classification and regression trees) algorithm, one of the most innovative methods of creating regression trees. The essence of the CART algorithm employed in the analysis is to perform recursive divisions of the so-called training set of observations into sub-sets until they become homogeneous, in terms of objects belonging to classes [56]. As recursive divisions are performed, each time the aim is to find, in the whole set of independent variables, a variable that will enable splitting that will ensure the greatest improvement in the goodness of fit. In other words, sub-sets that are internally most homogeneous but at the same time differ from each other are identified. The hierarchical structure resulting from successive divisions has a tree shape. It consists of nodes subject to splitting (if they are further split) and terminal nodes, the so-called leaves (where the splitting ends) [57].

The tool proposed by Breiman et al. [58] aims to search for a set of logical conditions that split the "if-then" relationship. Figure 2 presents an example of a regression tree explaining how the CART algorithm works.

When selecting the optimum split, the software tries to keep the average "impurity" of the two child nodes to a minimum. For a node t of the tree, the "impurity" is defined as the sum of squared deviations $i(t)=\sum\left(y-\bar{y}_{t}\right)^{2}$, where $\bar{y}_{t}$ is the sample mean of response variable $\mathrm{Y}$ in $\mathrm{t}$ and the sum is greater than the y values in $t$. The split of $t$ into child nodes $t L$ and $t R$ that maximises the reduction in node impurity $i(t)-i(t L)-i(t R)$ is selected. The division of the tree into nodes continues until the $\mathrm{y}$ values are constant in a given node, or the node sample size falls below a pre-defined limit value. The tree is then pruned by means of cross-validation and the sub-tree with the lowest estimated mean squared error is selected [14].

The employed research tool has a number of important advantages: there is no need to recode qualitative variables, there is no need for standardization of variables, variables do not have to have a normal distribution and the relationship between dependent and independent variables does not have to be linear. In addition to that, spatial autocorrelations cannot prevent the correct use of CART [59]. 


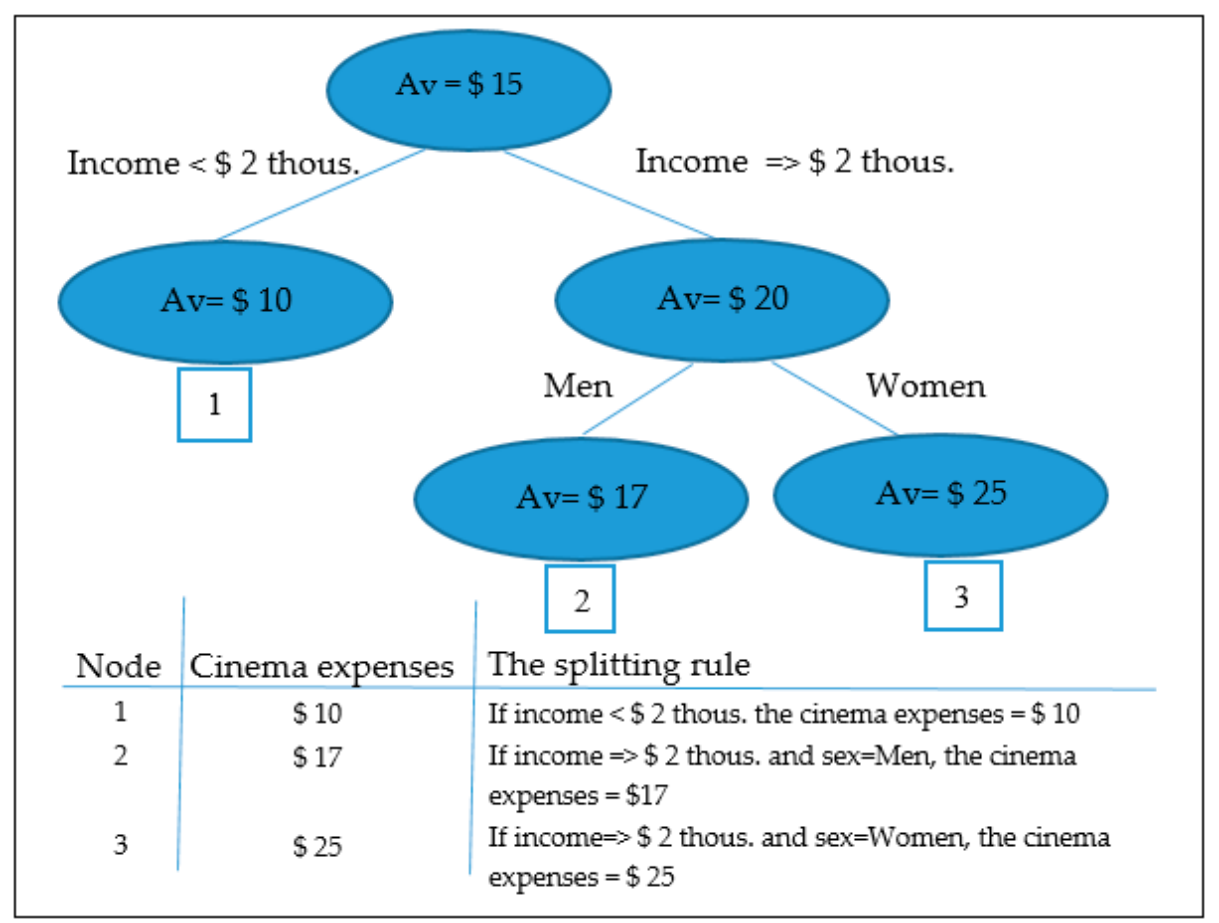

Figure 2. An example of a regression tree showing the factors impacting monthly cinema expenses. Source: [14].

A disadvantage of these models is a relatively high instability, as a small change to the training data (e.g., skipping a few observations) may result in a completely different classification [56]. Moreover, with a very large number of observations and splits, a tree becomes illegible. Therefore, when building a CART model it is important to specify parameters that will allow its quality to be assessed and prevent excessive expansion of the model.

In this paper, quality control of the obtained results was conducted using $\mathrm{v}$-fold cross validation $(v=10)$, and the process of creating new nodes of a tree was terminated by pruning at a minimum number of observations in the node subject to splitting $(n \geq 15)$ [57].

One output of the CART procedure considers the importance of the predictors, which are ranked in descending order of their contribution to tree construction. To calculate a predictor importance score, software calculates the improvement measure attributable to each variable in its role as a surrogate to the primary split. The values of these improvements are summed over each node of the tree and scaled relative to the best performing variable. The variable with the highest sum of improvements is scored 100, and all other variables have lower scores ranging downwards towards zero [60].

In this manuscript, the CART package available in Statistica 13.1 software (StatSoft Inc., Tulsa, OK, USA) was used.

\section{Research Findings}

\subsection{Location Matters: Generational Changes Depending on the Farm's Location}

After Poland's accession to the EU, new possibilities opened up in terms of impacting the pace and scope of structural transformations. "Early retirement" and "setting up of young farmers" granted under rural development programs and higher area payments for young farmers were meant to be the main incentive to accelerate generational changes in agriculture. The level of farmers' interest in securing such funds may constitute a basis for assessing the changes that take place in the agriculture of metropolitan areas.

The first stage of the analyses seeks to answer the question of whether the location of agricultural farms relative to the core of metropolitan areas determines generational changes. Analysis of the 
mean values of the examined indicators of the pace of generational changes in agriculture, as well as univariate analysis of variance (ANOVA), showed that there is a statistically significant variation in generational changes (level of interest in securing EU funds) in the analyzed groups of farms. Therefore, location should be considered as an important factor in the processes of generational changes on farms. However, analysis of the mean values for the different groups of farms-post-hocleast significant difference test (LSD tests) for group pair combinations-shows that statistically significant differences only occur in the case of farms located in the following zones: BCCM and ToPMA, as well as BCCM and OMA. At the level of $p=0.05$, there are no differences between farms in the ToPMA zone and those in the OMA zone, which means that the processes of generational changes are very similar in these zones. This applies to all of the analyzed variables.

Proceeding to more detailed analyses, it should be noted that the smallest variation across groups is observed in the case of variable I-1. In the BCCMA zone, around 8.1/1000 farmers receive payment for young farmers (CAP Pillar I), whereas in the ToPMA zone this figure is 9.6/1000, and in the OMA zone it is 9.2/1000 (Table 4). The differences are not big (although statistically significant when comparing BCCMA with ToPMA and BCCMA with OMA), which can be explained by the relatively easier access to this financial instrument (every young farmer receives payments). In contrast to the other (analyzed) measures, beneficiaries of payment for the young farmers (CAP Pilar I) also included people who were not insured in agricultural pension systems or owning small farms, etc., i.e., those who were not eligible to aid for young farmers or early retirement. The relatively small differences in the number of beneficiaries of this measure should be considered as a positive phenomenon, because it means that the share of young farmers in the BCCM zone, which is more at risk of the lack of successors in agriculture (well-developed off-farm labor market), is only slightly lower than in other areas.

Table 4. Overview of mean values of the scale of generational changes on univariate ANOVA and post-hoc LSD tests for group pair combinations (I-1-Young farmer, CAP Pillar I).

\begin{tabular}{|c|c|c|c|c|}
\hline \multirow{3}{*}{ Farms by Location } & \multicolumn{4}{|c|}{ I-1-Young Farmer-CAP Pillar I } \\
\hline & \multirow{2}{*}{ Mean } & \multicolumn{3}{|c|}{$p$-Values } \\
\hline & & ВССМА & ToPMA & OMA \\
\hline BCCMA & 8.1 & & & \\
\hline ToPMA & 9.6 & $0.0190 *$ & & \\
\hline OMA & 9.2 & 0.0358 * & 0.04210 & \\
\hline SUM & 9.1 & & te $\mathrm{ANOV}$ & \\
\hline
\end{tabular}

${ }^{*} p<0.01$. Source: own calculations based on data from ARMA and LDB Poland.

In terms of the aim of promoting generational changes in agriculture, i.e., increasing the viability of the whole sector, the "setting up of young farmers" measure is of particular importance. An aid of around 25,000 euro is granted to young farmers (under the age of 40) who can demonstrate in their business plan that the investment will have a positive impact on the development of their farm [49]. In the case of this program, farmers from the BCCMA zone applied for such funds twice less frequently than those from the other groups (Table 5). Comparing these findings with the relatively large number of farm managers receiving young farmers payments (Table 4), it should be stated that, in the BCCMA zone, the problem is not a lack of young people working on farms, but rather a lack of willingness or capacity (e.g., due to small economic potential, lack of capital) to develop the farm. At this stage of the analyses, it is impossible to definitely conclude what the cause is, but this issue will be further addressed later in the paper. 
Table 5. Overview of mean values of the scale of generational changes on univariate ANOVA and post-hoc LSD tests for group pair combinations (I-2-Young farmer, CAP Pillar II).

\begin{tabular}{|c|c|c|c|c|}
\hline \multirow{3}{*}{ Farms by Location } & \multicolumn{4}{|c|}{ I-2-Young Farmer-CAP Pillar II } \\
\hline & \multirow{2}{*}{ Mean } & \multicolumn{3}{|c|}{$p$-Values } \\
\hline & & ВССМА & ToPMA & OMA \\
\hline BCCMA & 2.1 & & & \\
\hline ToPMA & 4.6 & $0.0029 *$ & & \\
\hline OMA & 4.0 & 0.0085 * & 0.2881 & \\
\hline SUM & 3.9 & & te $\mathrm{ANOV}$ & \\
\hline
\end{tabular}

The last measure analyzed was "early retirement". The analyses showed that farmers were willing to benefit from this program, as on average as many as 14.5/1000 farmers transferred their agricultural holdings, receiving in return early retirement pensions (Table 6). It was found that farmers in the BCCMA zone seized the opportunity to transfer their farm less often compared to the others. The reason for their low interest in securing early retirement may have been unwillingness to sell or pass on land that might be of considerable value in the future (e.g., as a result of conversion to non-agricultural uses). There could also have been a problem of a structural nature, as one of the requirements for the purpose of enlarging farms of another agricultural producer is to reach the physical size greater than the average for the country or province. With high fragmentation of farmland (which is the case of peri-urban zones, see [61]), there might have been no candidates for taking over a small farm.

Table 6. Overview of mean values of the scale of generational changes on univariate ANOVA and post-hoc LSD tests for group pair combinations (I-3-Early retirement).

\begin{tabular}{|c|c|c|c|c|}
\hline \multirow{3}{*}{ Farms by Location } & \multicolumn{4}{|c|}{ I-3-Early Retirement } \\
\hline & \multirow{2}{*}{ Mean } & \multicolumn{3}{|c|}{$p$-Values } \\
\hline & & ВССМА & ToPMA & OMA \\
\hline BCСMA & 7.7 & & & \\
\hline ToPMA & 15.6 & $0.0001 *$ & & \\
\hline OMA & 15.5 & 0.0001 * & 0.9587 & \\
\hline SUM & 14.5 & & te $\mathrm{ANOV}$ & \\
\hline
\end{tabular}

Analyzing the spatial variation in the pace of generational changes, it should be noted that large differences exist between the individual regions of Poland (Appendix A: Figures A1-A3). Overall, in the northern part of the country, i.e., in the provinces where the Tricity, Greater Poland, and parts of Warsaw metropolitan areas are located, the pace of generational change is relatively high. The best situation is definitely in the province of Greater Poland (Wielkopolska), i.e., the region that has long been considered an area of commercial and modern family farming [62]. In this province, including in the farms located close to the core of MA, farmers were highly active in securing funds for generational changes. At the other extreme is the province of Lesser Poland (Małopolska), where both the share of young farmers and their interest in securing funds for generational changes is definitely the lowest. Quite surprisingly, in the areas belonging to the BCCMA zone of the Krakow metropolitan area, the share of young farmers receiving area payments is higher than in the rest of the province, which may suggest that the city has a positive impact on generational changes. It is in contrast with the trends in the other metropolitan areas, where this figure is much lower. In the other metropolitan areas, there is also a high variation in the analyzed indicators that cannot be explained by location relative to the cores of metropolitan areas. 
Summing up, the analyses showed that the location of farms had a significant impact on the variation in generational changes in agriculture. Farmers running farms located in the BCCMA zone obtained financial aid for generational changes less often than farmers in the OMA zone. This trend was not observed among farms located in the ToPMA zone, and the findings indicate that the process of generational changes there was similar to that in the areas outside of MAs.

\subsection{Drivers of Generational Changes}

One of the aims of this manuscript was to indicate factors determining the scale of generational changes in agriculture. The analyses covered selected metropolitan areas and areas around them (in the analyzed provinces). Therefore, the identified drivers of generational changes apply not only to metropolitan areas, but also to the agriculture around them.

The first model presents the impact of exogenous and endogenous factors on the number of young farmers (per 1000 farmers) receiving area payments (variable I-1-Young farmers CAP Pillar I). Although the variation (measured here by variance) of this variable is relatively small, several key variables impacting the number of young farmers were identified. The most important variable turned out to be the one showing the share of economically strong agricultural farms. This variable occurs twice in the regression tree and ranks first in the ranking of predictors (Figure 3). It should be noted that in areas where the share of economically strong farms is lower than $50.2 \%$, the number of young farmers is 8.0/1000, and where it is higher, the number of young farmers increases to 10.6/1000 (node $\mathrm{ID}=3$ ). Node ID $=3$ additionally splits based on the economically strong farms variable, making the previous result more precise. Taking into account the new split, it should be noted that if the share of economically strong farms is between 50.2 and $67.6 \%$, then the number of young farmers is on average $9.9 / 1000$, and if it is higher than $67.6 \%$, then there are 12.5 young farmers per 1000 farmers. A higher share of economically larger farms translates each time into a greater number of young farmers. Another variable that impacts the number of young farmers is the share of built-up and urbanized areas. In areas where the share of economically strong farms is between 50.2 and $67.6 \%$ and the percentage of urbanized and built-up areas is higher than $4.7 \%$, the number of young farmers is $8.8 / 1000$ (node ID = 13). A lower share of these areas means a larger number of young farmers; 10.2/1000 (node ID =12).

Further splits of the tree on its left-hand side show that in areas where economically small farms dominate (node ID =2), the number of young farmers is impacted by population density. It turns out that, in areas with population density above 78.1 people $/ \mathrm{km}^{2}$, there are fewer young farmers (node ID $=5$ ) than in less populated areas (node ID $=4$ ). A higher population density is therefore not conducive to a large number of young farmers.

The essence of a regression tree building is recursive divisions, where the divisions are performed using the best variable (one that improves the quality of the model), which, combined with giving preference to simple structure trees, results in exclusion of some variables from the tree. Such variables often explain the dependent variable only slightly more poorly. In addition to the constructed tree, it is also necessary to look at the ranking of variables (Figure 4). In the case of the variable illustrating the number of farmers receiving young farmers payments, the share of economically strong farms was definitely the most important variable. The "education" variable, which did not appear in the regression tree, was also of major importance. However, additional analyses showed that a high share of farm managers with a relatively high education level translated into a higher number of young farmers. The third place was occupied by the "population density" variable, which had a negative impact on the number of young farmers. The "location" variable, in turn, was of relatively low importance. Although, as shown in Section 4.1, the variable does have an important impact on the number of young farmers, it explains the phenomenon much more poorly than the other variables. 


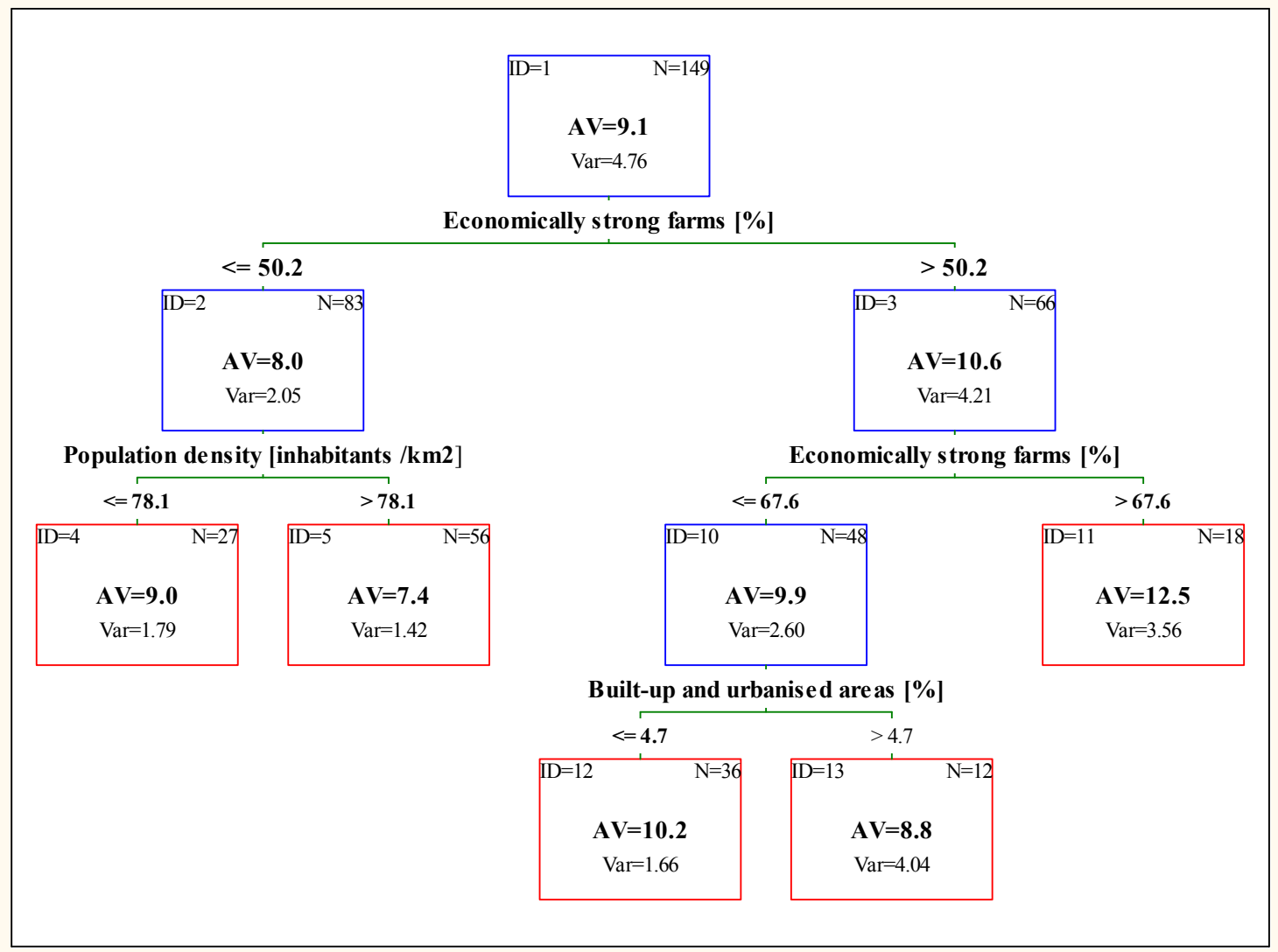

Figure 3. Regression tree diagram which shows predictors determining the number of young farmers benefiting from CAP Pillar I (Indicator I-1). Source: own elaboration.

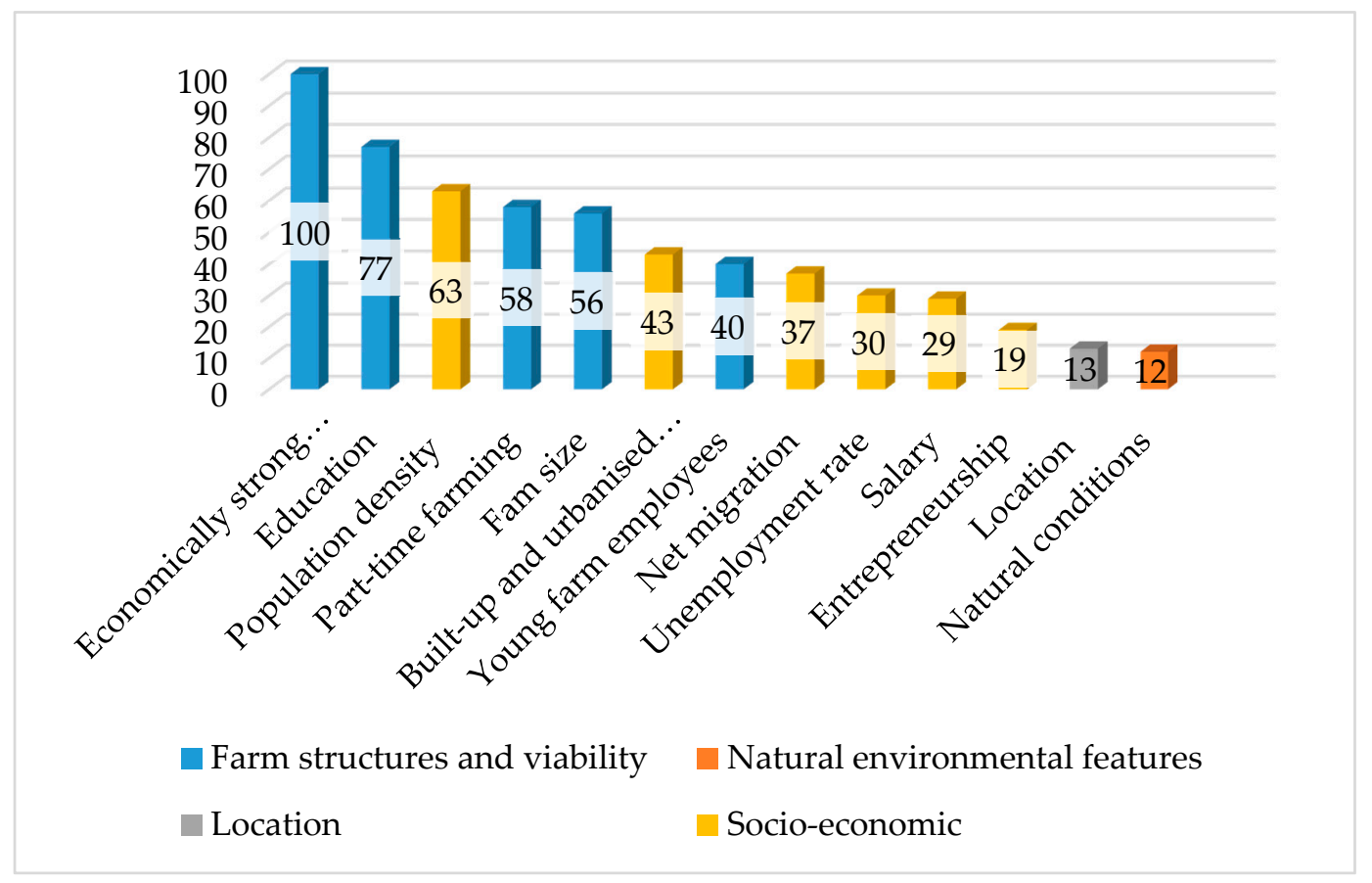

Figure 4. Importance of predictors in determining the number of young farmers benefiting from CAP Pillar I (I-1). Source: own elaboration. 
Figure 5 presents the results of modelling the I-2 variable, which represents the number of farmers who received "setting up of young farmers" grants under CAP Pillar II. As with the previous dependent variable, the first and second splits were performed based on the "economically strong farms" variable. Leaving aside the interpretation of node ID $=3$ (this is an intermediate node), it should be noted that in areas where the share of economically strong farms is less than $58 \%$, the number of young farmers is 2.7/1000 (node ID = 2), but when the share of economically strong farms increases to 58.0-67.6\% (node ID = 4), the number of young farmers increases to 5.9/1000. Further, when the share of economically strong farms exceeds $67.6 \%$, the number of young farmers is 9.1/1000 (node ID = 5). The economic size of farms is, in this case, a key factor that has a positive impact on generational changes in agriculture.

When assessing successive splits of the regression tree, it should be noted that in areas with a smaller percentage of economically strong farms (node ID $=2$ ), the number of young farmers is determined by population density. In areas where it exceeds 94.1 persons $/ \mathrm{km}^{2}$, the average number of young farmers is $1.6 / 1000$. Where density is lower, the figure is $3.7 / 1000$ farmers (node ID =6). Nodes ID $=5$ and ID $=6$ are subject to further splits, and in the case of the former, the number of young farmers is determined by the share of built-up and urbanized areas. Where the share of such areas is less than $4.9 \%$, the number of young farmers is $4.0 / 1000$, compared to 2.3 in more urbanized areas. In the case of node $\mathrm{ID}=7$, net migration rate is decisive. In areas with a lower net migration, the number of young farmers is higher (node ID $=10$ versus node ID $=11$ ).

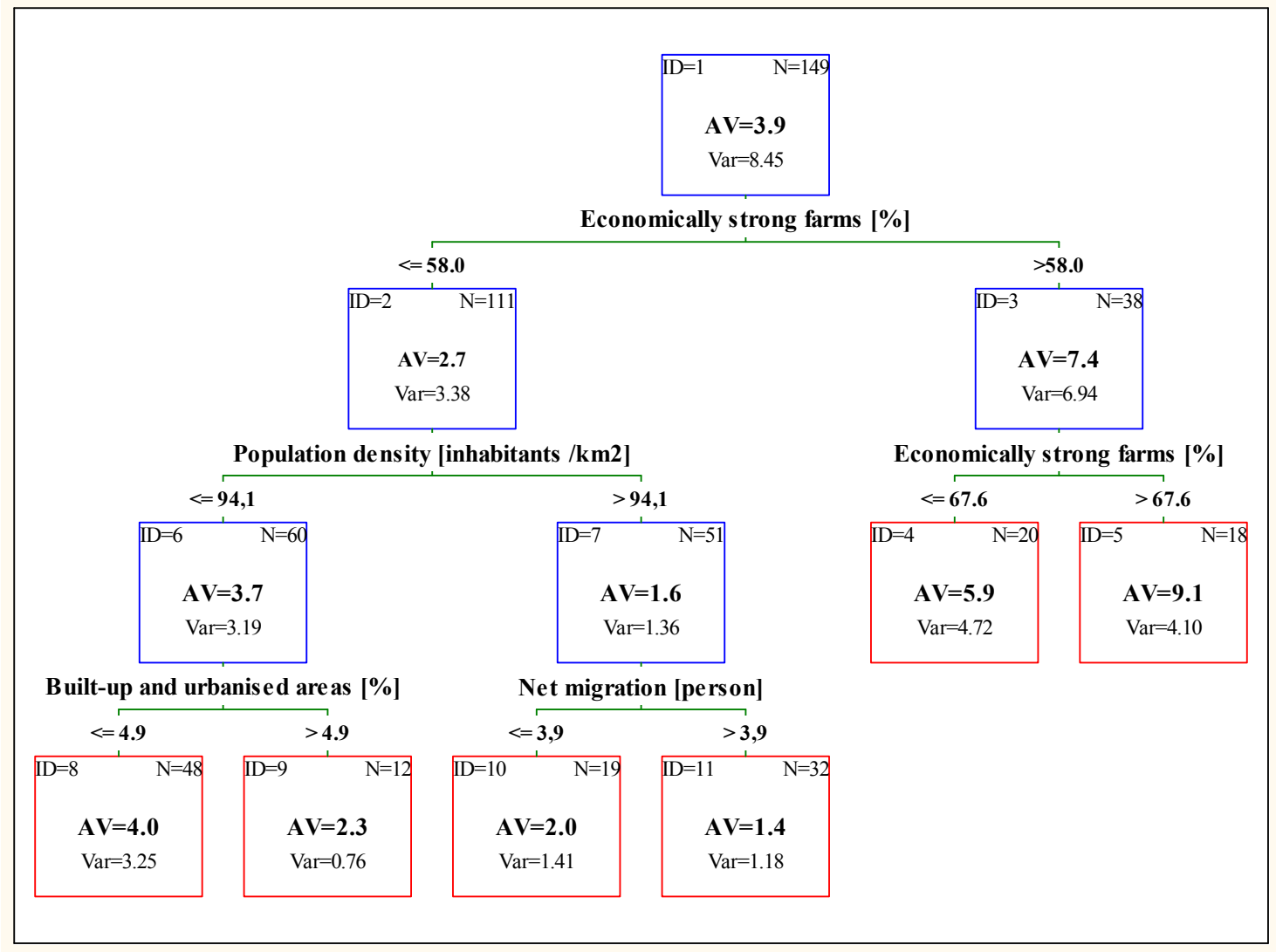

Figure 5. Regression tree diagram which shows predictors determining the number of young farmers benefiting from CAP Pillar II (Indicator I-2). Source: own elaboration.

As in the previous model, the variable that best determined the number of young farmers was the share of economically strong farms (Figure 6). The physical size of the farm and the level of education of farm managers were also of high importance. They had a positive impact on the chance of receiving funding and generational changes in agricultural farms. 


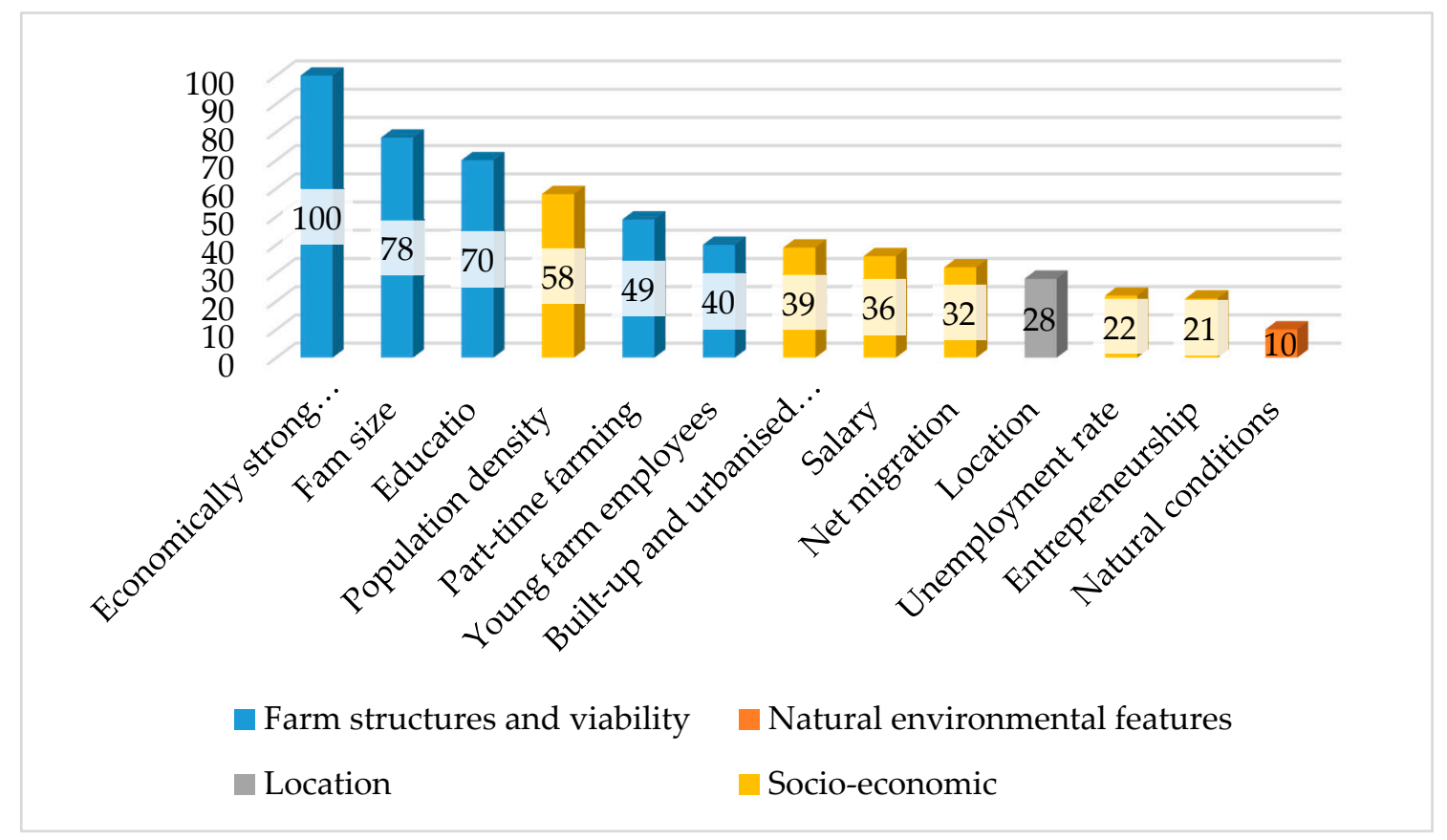

Figure 6. Importance of predictors in determining the number of young farmers benefiting from CAP Pillar II (Indicator I-2). Source: own elaboration.

The socio-economic variables of considerable importance included population density, the share of built-up and urbanized areas, salary, and net migration rate. Higher values of these variables had a negative impact on the processes of generational changes in agriculture. Also in this case, the location factor proved to be relatively insignificant.

Assessing generational changes in agriculture in terms of the number of farmers transferring farms in exchange for early retirement pensions, it should be noted that the most important factor accounting for differences in this process is the size of farms (Figures 7 and 8). The analysis of the tree diagram shows that in areas with an average farm size of over 9 ha, the number of farmers transferring farms was almost 18/1000, and in areas with a smaller farm size there were only 9.3/1000 farmers. Socio-economic variables, including population density and entrepreneurship, are also of great importance. It should be noted that in areas where the average farm size is less than 9 ha and the population density is over 112.5 people $/ \mathrm{km}^{2}$, fewer than $6 / 1000$ farmers (node ID = 5) applied for early retirement. With the same farm size characteristics but lower population density, farm transfers were more than twice as frequent (node ID $=4$ ). Population density impacts the processes of farm transfer also in the case of farms grouped in node ID $=8$, where, with a higher value of this indicator, 12.8/1000 farmers (node ID = 11) transferred their farms in exchange for early retirement, while with a lower value, 18.3/1000 (node ID =10), this was not the case. Both the variables negatively affect the number of farmers transferring their farms (as part of the assessed measure). Entrepreneurship is another important factor in generational changes. In areas where the average farm size exceeds 9 ha, a higher number of enterprises (above 1077.6/1000 population) is accompanied by a relatively low scale of farm transfers, only 9.2/1000 farmers, while in areas with a lower level of entrepreneurship, the scale of farm transfers is more than twice as high (node ID =6). Thus, a high level of non-agricultural entrepreneurship inhibits the processes of generational changes in agriculture. 


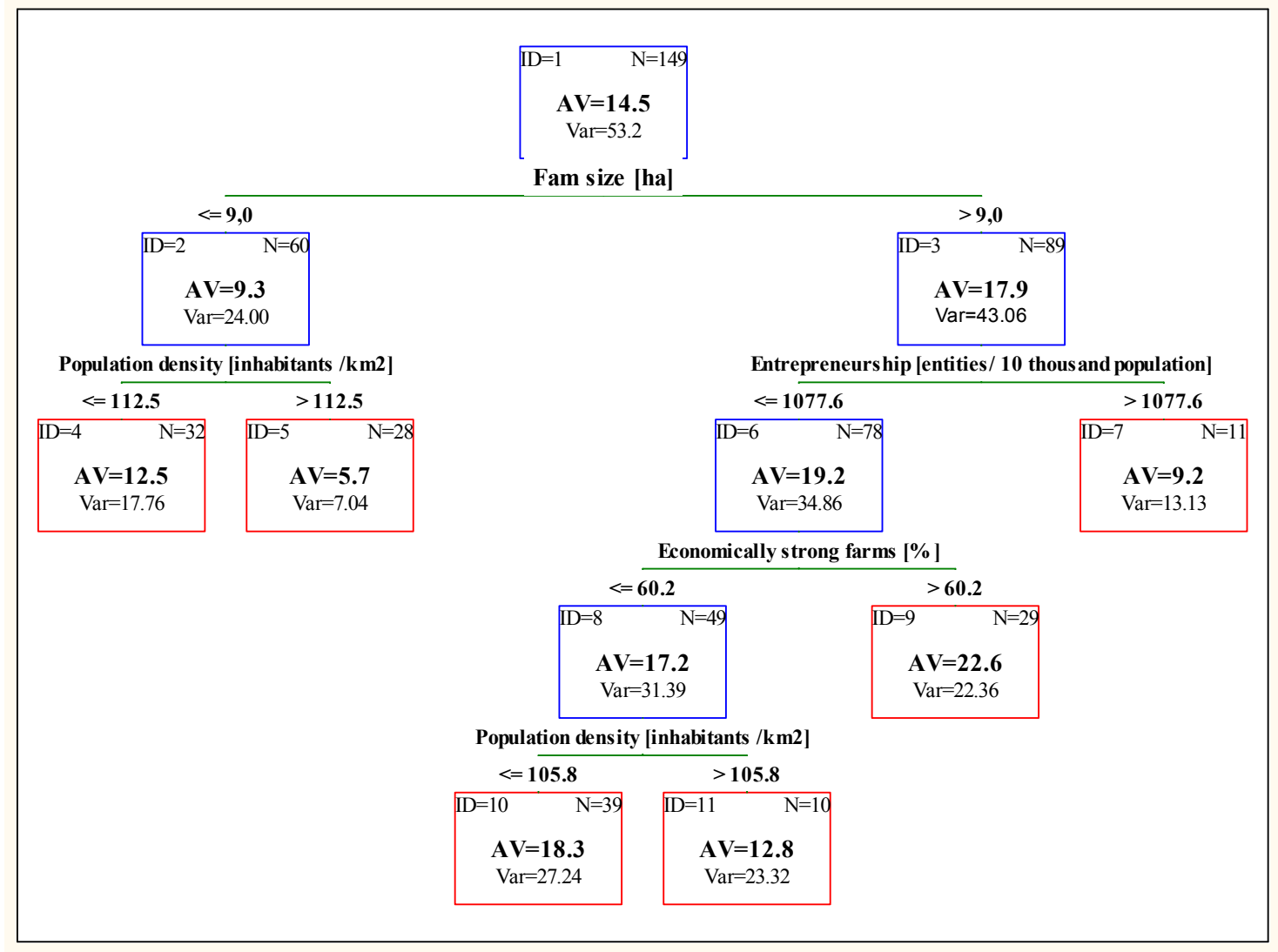

Figure 7. Regression tree diagram which shows predictors determining the number of beneficiaries of the "early retirement" program (Indicator I-3). Source: own elaboration.

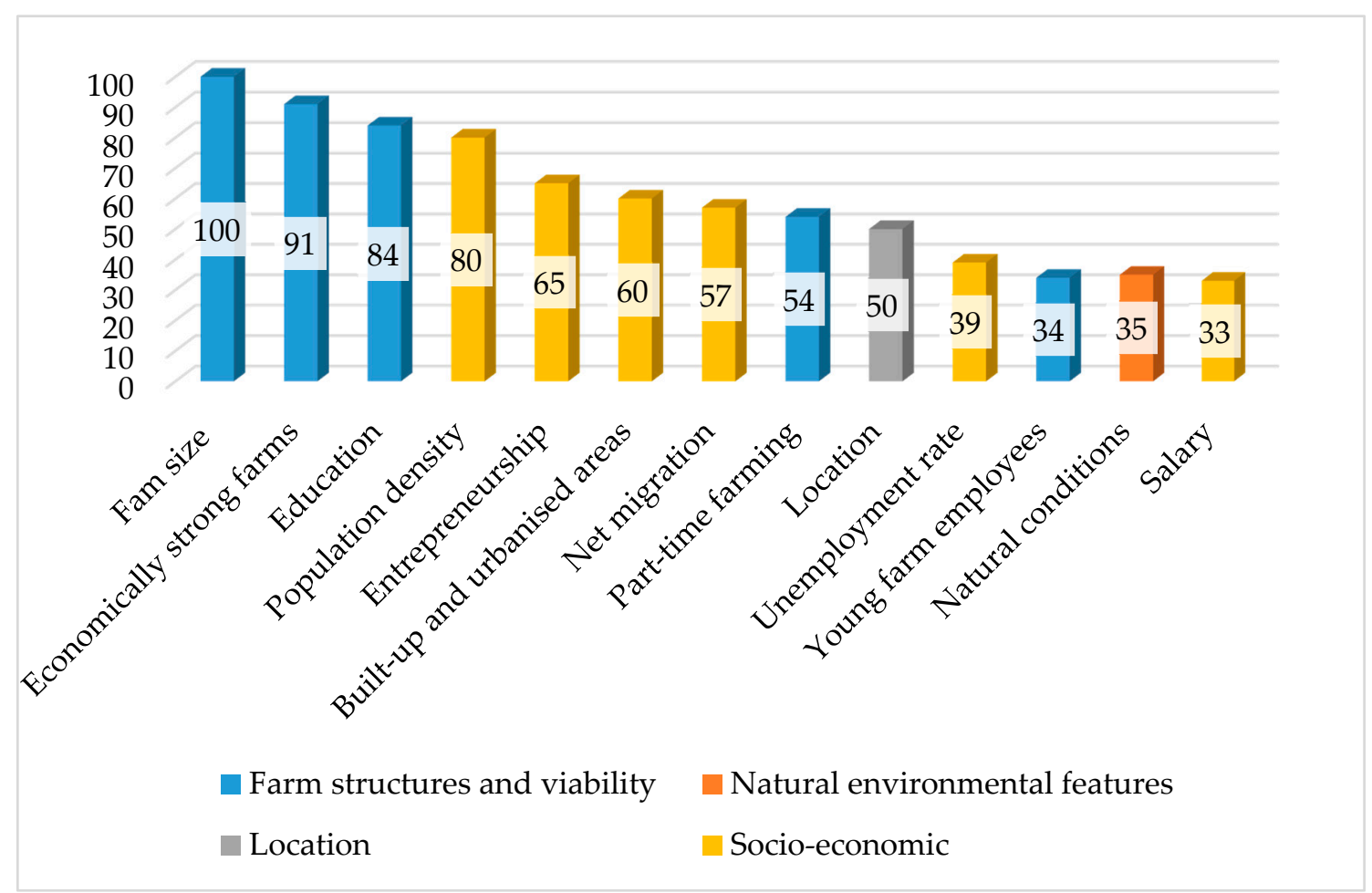

Figure 8. Importance of predictors in determining the number of beneficiaries of the "early retirement" program (indicator I-3). Source: own elaboration. 
Once again, the importance ranking is dominated by variables showing farm characteristics, including "farm size", "economically strong farms", and "education" (Figure 8). However, socio-economic variables, in particular population density and entrepreneurship, are also of considerable importance.

Also, the location factor turned out to be relatively important in describing the variation in farmers' interest in getting an early retirement. However, the farm's location relative to the core of the metropolitan area alone was not a factor determining the pace and extent of structural changes in agriculture. More important were the variables describing processes of urbanization (which depend on the distance from a large city), resulting in population movement, increased wealth of residents, and pressure to convert agricultural land to non-agricultural purposes.

\section{Discussion}

The pace and scope of changes occurring in agriculture are determined by a number of factors which are very difficult to identify and even more so to quantify [28]. An important element in the trends observed is the process of generational changes, where the established model of transferring resources from an older farmer to a younger successor (usually a son) has been redefined as a result of the dynamic development of non-agricultural sectors of the economy [63,64].

The first part of the investigation concerned the impact of farm location on the processes of generational changes (measured by farmers' interest in benefiting from public support). ANOVA analysis, together with post-hoc tests, showed that the scale of generational changes is statistically significantly lower in the zones directly bordering the core of the metropolitan area (BCCMA) than in the other zones (ToPMA and OMA). However, no statistically significant differences were recorded between farms located in the transition zone (ToPMA) and farms located outside the MA (OMA), albeit generational changes (all indicators) in the ToPMA zone occurred slightly faster. According to Wojewodzic and Sroka [15], the faster processes of structural transformation in the ToPMA zone can be explained by the faster rate of withdrawal from agricultural activity among owners of smaller farms. The authors point out that slightly further away from the MA core, it is very difficult to combine off-farm employment with running a farm. The lack of these trends (of exiting from farming by small farmers) in the BCCMA zone can, however, be explained by the occurrence of the phenomenon of rent seeking - the owners of agricultural land do not want to give up a number of privileges connected with being a farmer (area payments, large tax, and insurance preferences) and expecting the rise of the land price in the long-term [37]. This is not conducive to generational changes.

Comparing the obtained results with the studies of other scholars, a considerable contradiction was noticed. On the one hand, many studies indicate recessive processes in urban and peri-urban areas/metropolitan areas, and on the other hand, activities of adaptation and the economic success of farms are indicated, including a higher probability of succession. For instance, analyzing farming systems and land use in European rural-urban-regions, Zasada et al. [65] notes that "farming in urban environments is increasingly constrained and marginalized". Studies conducted in Central and Eastern European countries (Bulgaria, Poland, Latvia), as well as in some regions of Italy and Spain, also confirm the occurrence of recessive processes $[14,38,66,67]$. At the other extreme are studies confirming the economic success of farm adjustment processes in peri-urban areas in Western Europe, including Germany [14,39], Denmark [68], and Italy [29], and in the United States [32]. Many studies have shown that the proximity to the city has a positive impact on succession processes. This is due to greater development opportunities in the areas of multifunctional agriculture [39]. The location close to the city ensures an outlet for locally produced products (e.g., vegetables, flowers, etc.), and more importantly there is a high demand in such areas for various services provided by farmers [40]. In addition, the proximity of the city makes it easier to simultaneously run a farm and have an off-farm job, which is also conducive to succession [17]. The reverse situation in Poland may be the result of a relatively slow process of structural changes and the continued prevalence of farms with low economic potential. Further, in Polish metropolitan areas, only a few farms have adapted their activities to peri-urban 
conditions [69], and, in recent years (since 2004), these areas have seen a slower rate of economic development compared to that outside metropolitan areas [15]. The concept of urban agriculture is little known in Poland, and the functions and benefits of urban agriculture are much less recognized than, for example, in Germany or Italy [3,45].

Although the analyses using univariate ANOVA found the "location" variable to be significant, regression tree models showed a relatively small significance of farm location in explaining processes of generational changes. The variables describing farm structures and socio-economic variables ranked much higher in importance. It results partly from the nature of the "location" variable (dummy variable), and above all from its distribution, i.e., large asymmetry. The large number (over-representation) of the entities in the OMA group (100/149 poviats), i.e., lumping together very diverse entities located outside the MA (high variance of most of the variables), meant that this variable relatively poorly explained the variation of generational changes.

Nevertheless, in regression models, socio-economic variables, which are very closely related to location, were of relatively considerable significance (see Table 2). In all the regression models, there were clear trends showing that an increase in the degree of urbanization (higher population density, positive net migration) and higher attractiveness of the labor market (higher salaries, stronger entrepreneurship, lower unemployment) negatively affect the processes of generational changes. The observed relationship regarding the negative impact of an attractive labor market on farm succession is consistent with occupational choice theory [5]. High salaries, low unemployment, and a large number of enterprises have a negative impact on the decisions to take over farms, because there is a chance of a better paid and more prestigious off-farm job [10]. This is particularly the case with farms characterized by lower economic potential which are unlikely to generate sufficient income [70]. In Polish metropolitan areas, about $50 \%$ of farms have an economic size below 15,000 EUR, and the income of such farms does not exceed 6000 euro annually. Bertoni and Cavicchioli [29] present different results, but their analyses cover horticultural farms that generate relatively high income. According to their research, higher rates of non-agricultural employment and higher salaries have a positive impact on succession, as a more prosperous society is more likely to buy products directly from local farms.

The negative impact of higher population density and high net migration demonstrated in the manuscript can be explained by means of the rent bid theory [71]. Increase in population density and migrations lead to growing demand for land for non-agricultural purposes [72]. As Alonso [71] noted, higher economic rents generated by the development of house building contribute to a decrease in the area of land used for agricultural purposes. Also, Mazzocchi et al. [52] noted that with high pressure from the non-agricultural sector, agriculture loses competition for land, which results in farmland conversion into non-agricultural purposes. The impact of a positive net migration can be explained along the same lines-new residents need space in order to live and work, hence the loss of agricultural land and smaller chances of farm development [45]. In addition, the net migration is strongly correlated with both the average salary (Pearson correlation coefficient $=0.28$ ) and entrepreneurship (correlation coefficient $=0.58$ ), as well as unemployment rate (correlation coefficient $=-0.46$ ). Thus, the same areas experience a doubled negative effect on generational changes: on the one hand, an attractive labor market encourages farmers to leave the agricultural sector, and on the other, competition for land inhibits farm development processes (the effect of land speculation also plays a significant role) $[37,38]$. In such conditions, mainly multifunctional and specialized farms (e.g., vegetable, fruit, etc.), which do not need to increase their agricultural area to grow, have a chance of development (and succession) [39,40]. The significant gap between the situation in Poland and in other Western European countries, as pointed out by Sroka et al. [14], may paradoxically result from the much larger scale of farm exits in developed countries in the past. In these countries, areas with very high population density are currently dominated by farms that are well adapted to urban conditions and generate relatively high incomes.

In these analyses, the emphasis has been placed on the assessment of exogenous factors, including those related to the socio-economic situation of the area where the farms are located. However, 
the executed studies found that the most important factors were the variables characterizing farm structures and viability, and in particular economic and physical size of farms $[6,10,21,73]$. In the case of the models explaining variables I-2 and I-3, i.e., the ones showing the number of beneficiaries of CAP Pillar II, measures "early retirement" and "setting up of young farmers", this is in a way the effect of the assumptions of these programs. In principle, these measures preferred physically and economically larger farms. Nevertheless, a very high importance of farm size was also observed in the first model, which presented the drivers of the variation in the number of farmers benefiting from the young farmer payments (CAP Pillar I), where economic size was also the most important factor. These observations confirm the trends noted in other studies, where it is emphasized that economically strong and high-income farms are more often successfully transferred to successors $[6,25,26]$.

The variations in the use of CAP measures aimed at generational changes in agriculture resulting from the different economic potential of farms were also documented by the research findings at the level of the six analyzed metropolitan areas. The greater use of those instruments in the Central-Western part of Poland was noted. This area is usually considered as a region of commercial and modern family farming [62]. On the other hand, there was the province of Lesser Poland [Małopolska] in the southern part of the country, where both the share of young farmers and their interest in securing funds for generational changes were definitely the lowest. A relatively large number of small and semi-subsistence farms were functioning in the Lesser Poland [26]. At the same time, a high level of non-agricultural employment and diversification of local economies was observed there, and as a result it limited the use of analyzed agricultural policy programs.

The investigation also showed high importance of the "education" variable, and additional analyses indicated that a higher percentage of farm managers with at least secondary agricultural education is conducive to generational change. As pointed out by Cavicchioli et al. [16], better education is usually accompanied by better economic results achieved by farms, and hence, succession is more common among them. However, parents with a high level of education usually strive to provide a good education to their children, who can then choose an off-farm job [29]. In our research, the first effect trumps the second, which is also confirmed by research done by other scholars $[20,74]$.

\section{Conclusions}

The study demonstrated that generational changes in agriculture, measured by the level of the use of agricultural policy instruments focused on structural transformations, were a complex issue, determined by a number of factors. Conducted analyses increase the knowledge about the impact of exogenous factors, in particular the socio-economic situation of dynamically developing metropolitan areas, on generational changes in agriculture.

The findings indicate that in areas with the highest pressure of urbanization, i.e., areas bordering the cores of metropolitan areas, the occurrence of generational changes is statistically significantly less frequent than in areas further away from dynamically developing cities. Thus, a location close to the market and in highly populated areas is not conducive to generational changes in Polish farms. Our findings are not consistent with the research conducted in other countries, especially highly developed ones, where urban and peri-urban farms are more often passed on to successors. In Poland, the main barrier to successful generational farm transfer is the low economic (and income) potential of farms, hence agriculture is becoming increasingly less profitable than other sectors. High population density and a positive net migration hamper the development of farms (through an increase in farm size), which is not conducive to succession, and the attractive urban labor market "drains" the population from the agricultural sector. The literature indicates that this process can be stopped when farmers receive satisfactory incomes, and these are generated in farms of large economic (not necessarily physical) size. The chance for stimulating generational changes is offered by the multifunctional development of agriculture, in particular the development of various services.

Therefore, it should be noted that the scale of generational changes in the agricultural sector in the areas studied is primarily related to endogenous factors, i.e., the agrarian structure in the examined 
areas, and in particular the economic size of the farm in a given area. Exogenous factors, including farm environment, can merely additionally stimulate (if the potential of the market is exploited) or limit the processes of generational changes. The observed phenomenon was consistent with the literature. Relatively higher succession rates and interest in the expansion of agricultural activity using CAP funds are mainly seen among farms characterized by a relatively higher economic strength.

Regarding generational renewal in agriculture, our research demonstrates that analyzed CAP instruments are less effective in the case of (economic) small farms, as well as in areas with stronger urbanization pressure. In the studied areas, these problems most often overlap, because the growing urbanization pressure inhibits the growth of the economic potential of peri-urban farms, which in turn results in lower dynamics of generational changes. As part of the CAP, actions should be taken to strengthen the economic potential of small farms, e.g., through improvement in the organization of the food chain, with particular attention to the short food chain. Examples from other countries presented in the manuscript indicate that such activities bring the expected results. The analyses presented in this manuscript have several limitations. It should be noted that our research did not refer all generational changes in the agricultural sector in the areas studied. The analyses only covered farms benefiting from various instruments of agricultural policy, which certainly is a research limitation and demands some caution when interpreting the findings. Nevertheless, the study addresses the issues of generational changes and succession in agriculture from a unique perspective. Unlike many studies of intergenerational succession, it includes actual data (rather than being based on declarations) aggregated at the level of subregions (rather than households). Its originality also lies in an attempt to define the effect of the phenomena shaped by the largest urban centers in the socio-demographic structures of family farming at the supra-regional level.

According to the authors, subsequent studies should focus on an attempt to analyze succession factors in small farms located in the BCCMA zone. In particular, they should take into account the impact of the effect of rent seeking, including speculation, which hinder a successful transfer of farms, as well as the importance of adjustment strategies.

Author Contributions: Conceptualization, W.S., T.W., and M.D.; methodology, W.S.; software, W.S.; validation, W.S., T.W., and M.D.; formal analysis, W.S., T.W., and M.D.; investigation, W.S., T.W., and M.D.; data curation, T.W.; writing - preparation of original draft, W.S., T.W., and M.D.; writing-review and editing, W.S., M.D., and K.K.; visualization, K.K. and W.S.; project administration, W.S. and K.K.; acquisition of funding, W.S.

Funding: This research was funded by the National Science Centre, Poland, under project no. 2016/21/D/HS4/00264.

Acknowledgments: We would like to express our thanks to the editor and the reviewers for their valuable comments and for the detailed suggestions they made on how to improve the paper.

Conflicts of Interest: The authors declare that they have no conflict of interest. The funders had no role in the design of the study; in the collection, analyses, or interpretation of data; in the writing of the manuscript, or in the decision to publish the results. 
Appendix A

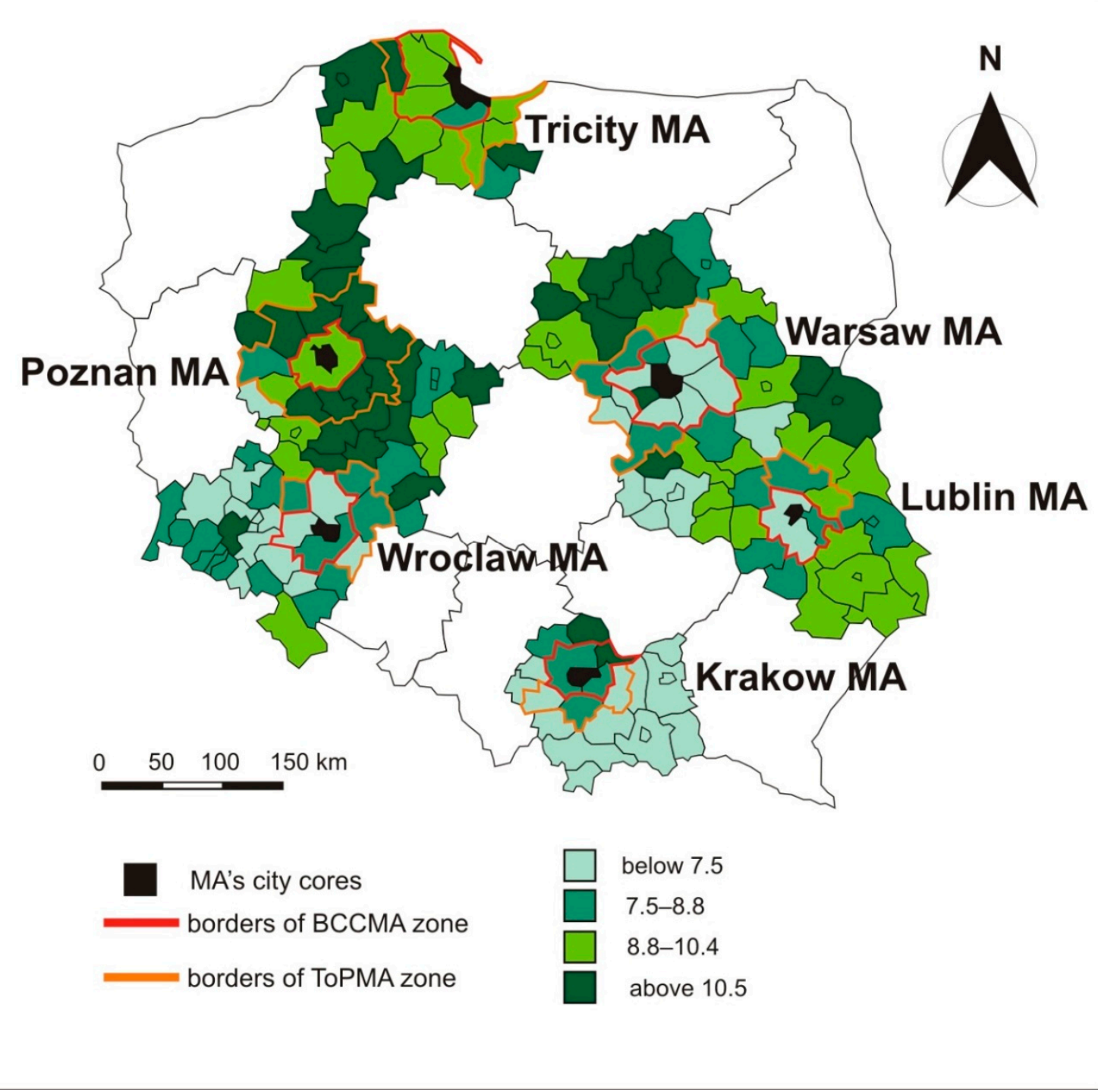

Figure A1. Number of beneficiaries of the young farmer payment per 1000 farms benefiting from direct payments (average for 2015-2017). Source: own elaboration. 


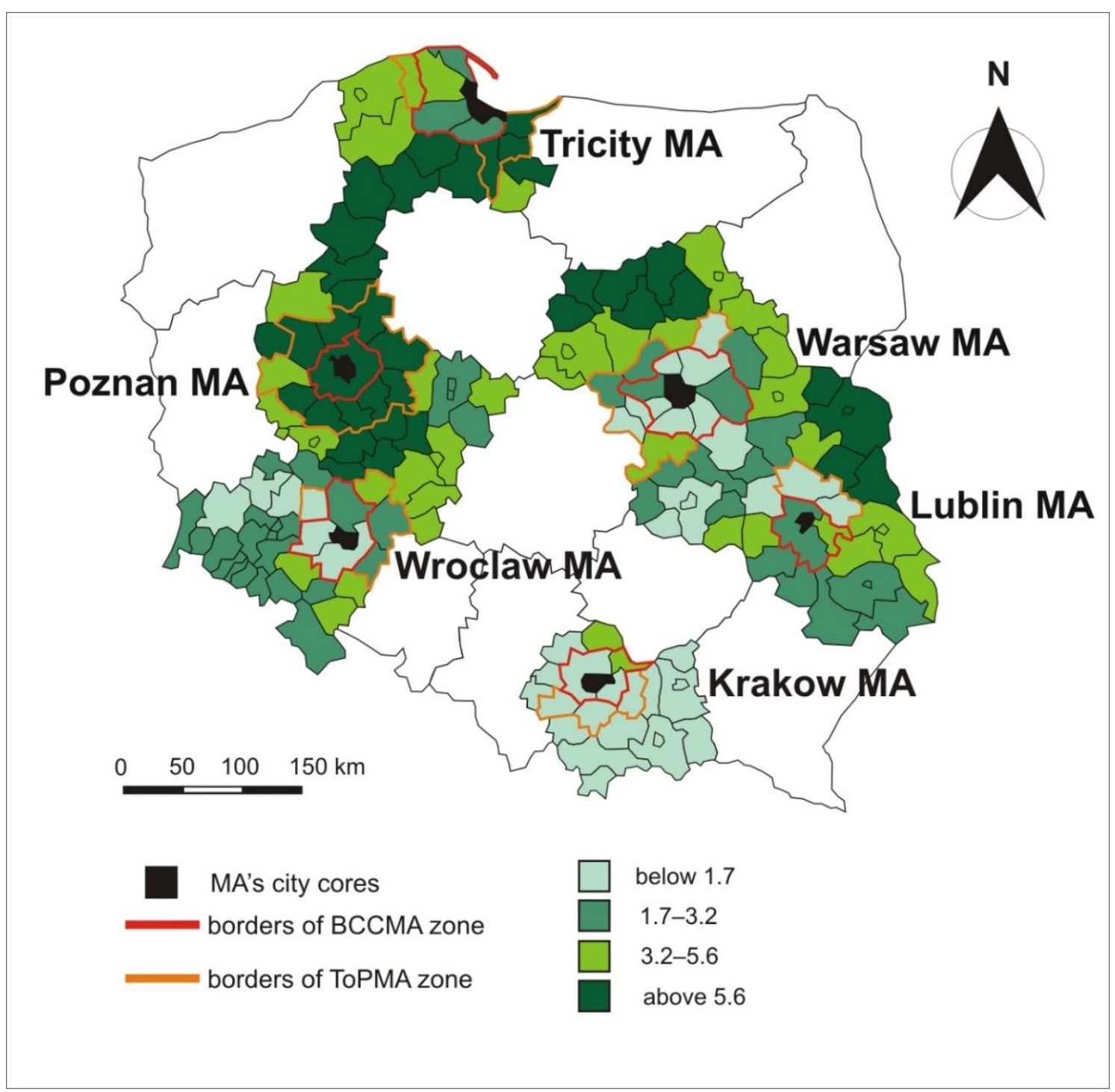

Figure A2. Number of beneficiaries of "setting up of young farmers" grants per 1000 farms benefiting from direct payments (average for 2007-2017). Source: own elaboration. 


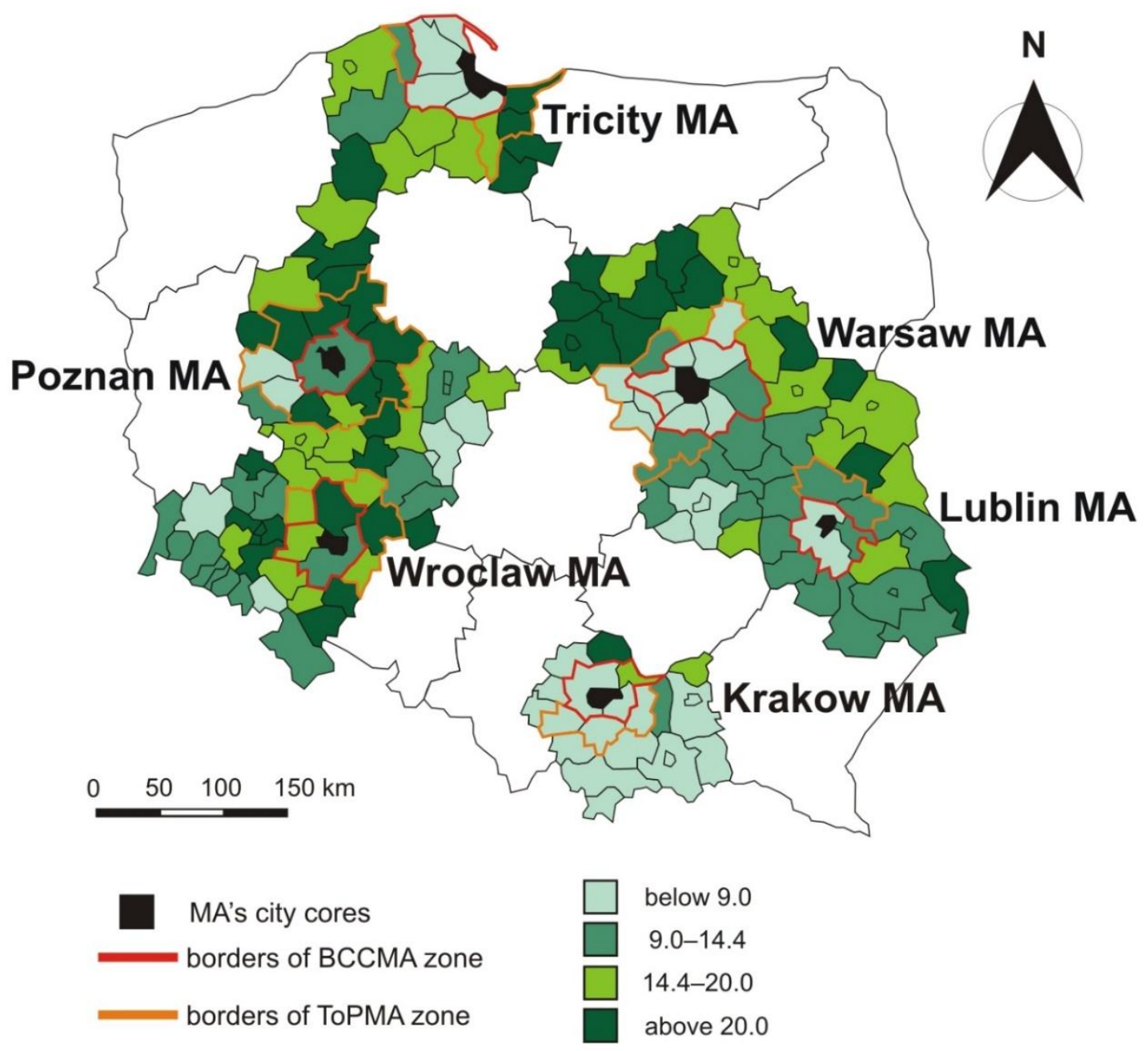

Figure A3. Number of beneficiaries of "early retirement" grant per 1000 beneficiaries of direct payments (average for 2007-2010). Source: own elaboration.

\section{References}

1. Mougeot, L.J.A. Growing Better Cities: Urban Agriculture for Sustainable Development; International Development Research Centre: Ottawa, ON, Canada, 2006.

2. Lovell, S.T. Multifunctional urban agriculture for sustainable land use planning in the United States. Sustainability 2010, 2, 2499-2522. [CrossRef]

3. Specht, K.; Weith, T.; Swoboda, K.; Siebert, R. Socially acceptable urban agriculture businesses. Agron. Sustain. Dev. 2016, 36, 17. [CrossRef]

4. Sroka, W. Perception of Benefits of Urban and Peri-Urban Agriculture-A Study in Polish Metropolitan Areas. Rocz. Nauk. Stowarzyszenia Ekon. Rol. Agrobiz. 2018, XX, 236-242. [CrossRef]

5. Cavicchioli, D.; Bertoni, D.; Frisio, D.G.; Pretolani, R. Does the future of a farm depend on its neighbourhood? Evidence on intra-family succession among fruit and vegetable farms in Italy. Agric. Food Econ. 2019, 7, 10. [CrossRef]

6. Dudek, M. A matter of family? An analysis of determinants of farm succession in Polish agriculture. Stud. Agric. Econ. 2016, 118, 61-67. [CrossRef]

7. Gasson, R.; Errington, A. The Family Farm Business; CAB International: Wallingford, CT, USA, 1993. 
8. Burton, R.J.F.; Fischer, H. The succession crisis in European agriculture. Sociol. Rural. 2015, 55, $155-166$. [CrossRef]

9. Wojewodzic, T. Pozorna sukcesja-Zaburzenie cyklu życia gospodarstw rolniczych. Zesz. Nauk. Szkoły Głównej Gospod. Wiej. Warszawie. Ekon. Organ. Gospod. Żywnościowej 2013, 103, 141-152.

10. Corsi, A. Family farm succession and specific knowledge in Italy. Riv. Econ. Agrar. 2009, 64, 13-30.

11. European Commission. Generational Renewal in EU Agriculture: Statistical Background, EU Agricultural Economic Briefs, Brief No 6. Available online: https://ec.europa.eu/info/sites/info/files/food-farming-fisheries/ farming/documents/agri-economics-brief-06_en.pdf (accessed on 14 September 2019).

12. Zagata, L.; Sutherland, L.-A. Deconstructing the "young farmer problem": Towards a research agenda. J. Rural Stud. 2015, 38, 39-51. [CrossRef]

13. Agra CEAS Consulting 2003. Ex-Post Evaluation of Measures under Regulation (EC) No 950/97. In Final Report for the European Commission Directorate-General for Agriculture. 2003. Available online: https:/ec.europa.eu/agriculture/sites/agriculture/files/evaluation/rural-development-reports/2003/ 951/full.pdf (accessed on 15 August 2019).

14. Sroka, W.; Pölling, B.; Mergenthaler, M. City adjustments as the main factor of success of urban and peri-urban farms-empirical evidence from the Ruhr metropolis. NJAS-Wagening. J. Life Sci. 2019, 89. [CrossRef]

15. Wojewodzic, T.; Sroka, W. Commercial Farms in Polish Metropolitan Areas: Changes in Production Factors. WieśRol. 2018, 4, 91-110. [CrossRef]

16. Cavicchioli, D.; Bertoni, D.; Pretolani, R. Farm succession at a crossroads: The interaction among farm characteristics, labour market conditions, and gender and birth order effects. J. Rural Stud. 2018, 61, 73-83. [CrossRef]

17. AldanondoOchoa, A.M.; Casanovas Oliva, V.; AlmanasaSaez, C. Explaining farm succession: An impact of farm location and off-farm employment opportunities. Span. J. Agric. Res. 2007, 5, 214-225. [CrossRef]

18. Alasia, A.; Weersink, A.; Bollman, R.D.; Cranfield, J. Off-farm labour decision of Canadian farm operators: Urbanization effects and rural labour market linkages. J. Rural Stud. 2009, 25, 12-24. [CrossRef]

19. Calus, M.; Van Huylenbroeck, G.; Van Lierde, D. The relationship between farm succession and farm assets on Belgian farms. Sociol. Rural. 2008, 48, 38-56. [CrossRef]

20. Mishra, A.K.; El-Osta, H.S.; Shaik, S. Succession decisions in U.S. family farm business. J. Agric. Resour. Econ. 2010, 35, 133-152. [CrossRef]

21. Lobley, M.; Baker, J.R. Succession and retirement in family farm business. In Keeping it in the Family. International Perspectives on Succession and Retirement on Family Farms; Lobley, M., Baker, J.R., Whitehead, I., Eds.; Ashgate Publishing Company: Farnham, UK, 2012; pp. 49-64.

22. Zegar, J.S. Kwestia Agrarna w Polsce; IERiGŻ-PIB: Warszawa, Poland, 2018.

23. Woś, A. Mechanizmy Restrukturyzacji Rolnictwa; Komunikaty Raport Ekspertyzy 449; IERiGŻ: Warszawa, Poland, 1999.

24. Whitehead, I.; Lobley, M.; Baker, J.R. From generation to generation: Drawing the threads together. In Keeping it in the Family. International Perspectives on Succession and Retirement on Family Farms; Lobley, M., Baker, J.R., Whitehead, I., Eds.; Ashgate Publishing Company: Farnham, UK, 2012; pp. 211-240.

25. Glauben, T.; Petrick, M.; Tietje, H.; Weiss, C. Probability and timing of succession or closure in family firms: A switching regression analysis of farm households in Germany. Appl. Econ. 2009, 41, 45-54. [CrossRef]

26. Dudek, M. Sukcesja Indywidualnych Gospodarstw Rolnych Jako Czynnik Przeobrażeń Strukturalnych w Polskim Rolnictwie; Studia i Monografie No. 170; IERiGŻ-PIB: Warszawa, Poland, 2016.

27. Fischer, H.; Burton, R.J.F. Understanding farm succession as socially constructed endogenous cycles. Sociol. Rural. 2014, 54, 417-436. [CrossRef]

28. Viira, A.-H.; Poder, A.; Varnik, R. Discrepancies between the intentions and Behaviour of farm operators in the context of farm growth, decline, continuation and exit-evidence from Estonia. Ger. J. Agric. Econ. 2014, 63, 46-62. [CrossRef]

29. Bertoni, D.; Cavicchioli, D. Farm succession, occupational choice and farm adaptation at the rural-urban interface: The case of Italian horticultural farms. Land Use Policy 2016, 57, 739-748. [CrossRef]

30. Glauben, T.; Tietje, T.; Weiss, C.R. Intergenerational succession in farm households: Evidence from Upper Austria. Rev. Econ. Househ. 2004, 2, 443-462. [CrossRef]

31. Wierzbicka, W. Czynniki lokalizacji przedsiębiorstw w warunkach zmienności otoczenia. Zesz. Nauk. Uniww. Przyr.-Humanist. Siedlcach Ser. Adm. Zarzadzanie 2015, 33, 239-250. 
32. Inwood, S.M.; Sharp, J.S. Farm persistence and adaptation at the rural-urban interface: Succession and farm adjustment. J. Rural Stud. 2012, 28, 107-117. [CrossRef]

33. Smętkowski, M. The Metropolisation Process on Different Territorial Scales: Focus on Capital City Regions in Central and Eastern European Countries; GRINCOH Working Paper Series, Paper No. 6.06, 2014. Available online: http://www.grincoh.eu/media/serie_6_spaces_territories_and_regions/grincoh_wp6.06_smetkowski. pdf (accessed on 14 September 2019).

34. Chmieliński, P. Labour markets for rural population: Commuting and migration abroad. Econ. Agric. 2013, 60, 511-521. [CrossRef]

35. Piorr, A.; Ravetz, J.; Tosics, I. Peri-Urbanisation in Europe: Towards European Policies to Sustain Urban-Rural Futures; Forest \& Landscape; University of Copenhagen: Copenhagen, Denmark, 2011.

36. Olper, A.; Raimondi, V.; Cavicchioli, D.; Vigani, M. Do CAP payments reduce farm labour migration? A panel data analysis across EU regions. Eur. Rev. Agric. Econ. 2014, 41, 843-873. [CrossRef]

37. Satoła, L.; Wojewodzic, T.; Sroka, W. Barriers to exit encountered by small farms in light of the theory of new institutional economics. Agric. Econ. 2018, 64, 277-290. [CrossRef]

38. Gradinaru, S.R.; Ioja, C.I.; Onose, D.A.; Gavrilidis, A.A.; Patru-Stupariu, I.; Kienast, F.; Hersperger, A.M. Land abandonment as a precursor of built-up development at the sprawling periphery of former socialist cities. Ecol. Indic. 2015, 57, 305-313. [CrossRef]

39. Zasada, I. Multifunctional peri-urban agriculture-A review of societal demands and the provision of goods and services by farming. Land Use Policy 2011, 28, 639-648. [CrossRef]

40. Pölling, B.; Mergenthaler, M.; Lorleberg, W. Professional urban agriculture and its characteristic business models in Metropolis Ruhr, Germany. Land Use Policy 2016, 58, 366-379. [CrossRef]

41. Lohrberg, F.; Licka, L.; Scazzosi, L.; Timpe, A. Urban Agriculture Europe; JOVIS Verlag GmbH: Berlin, Germany, 2015.

42. Wästfelt, A.; Zhang, Q. Reclaiming localisation for revitalising agriculture: A case study of peri-urban agricultural change in Gothenburg, Sweden. J. Rural Stud. 2016, 47, 172-185. [CrossRef]

43. Pölling, B.; Sroka, W.; Mergenthaler, M. Success of urban farming's city-adjustments and business models-Findings from a survey among farmers in Ruhr Metropolis, Germany. Land Use Policy 2017, 69, 372-385. [CrossRef]

44. Klank, L. Sukcesja Gospodarstw Rolnych w Polsce; IRWiR PAN: Warszawa, Poland, 2006.

45. Sroka, W.; Mikolajczyk, J.; Wojewodzic, T.; Kwoczyńska, B. Agricultural land vs. urbanisation in chosen Polish Metropolitan areas: A spatial analysis based on regression trees. Sustainability 2018, 10. [CrossRef]

46. Bański, J. Changes in agricultural land ownership in Poland in the period of the market economy. Agric. Econ. 2011, 57, 93-101. [CrossRef]

47. Ministerstwo Rozwoju Regionalnego. KoncepcjaPrzestrzennego Zagospodarowania Kraju 2030; Ministerstwo Rozwoju Regionalnego: Warszawa, Poland, 2011.

48. European Commission. Direct Payments. The Young Farmer Payment under Pillar I of the Common Agricultural Policy. Available online: https:/ec.europa.eu/agriculture/sites/agriculture/files/direct-support/ direct-payments/docs/young-farmer-payment_en.pdf (accessed on 14 September 2019).

49. Adamowicz, M.; Szepeluk, A. Wsparcie młodych rolników jako element polityki rolnej Unii Europejskiej. ZagadnieniaEkon. Rolnej 2016, 3, 106-128. [CrossRef]

50. Pięta, P. Farmer's Pensions as an Instrument of Changing the Agrarian Structure in Poland. Socioecon. Chall. 2018, 2, 60-65. [CrossRef]

51. Witek, T. Waloryzacja Rolniczej Przestrzeni Produkcyjnej Polski Wedtug Gmin; IUNG: Puławy, Poland, 1994.

52. Mazzocchi, C.; Sali, G.; Corsi, S. Land use conversion in metropolitan areas and the permanence of agriculture: Sensitivity Index of Agricultural Land (SIAL), a tool for territorial analysis. Land Use Policy 2013, 35, 155-162. [CrossRef]

53. Suess-Reyes, J.; Fuetsch, E. The future of family farming: A literature review on innovative, sustainable and succession-oriented strategies. J. Rural Stud. 2016, 47, 117-140. [CrossRef]

54. Cavicchioli, D.; Bertoni, D.; Tesser, F.; Frisio, D.G. What factors encourage intrafamily farm succession in mountain areas? Mt. Res. Dev. 2015, 35, 152-160. [CrossRef]

55. Diogo, V.; Koomen, E.; Kuhlman, T. An economic theory-based explanatory model of agricultural land-use patterns: The Netherlands as a case study. Agric. Syst. 2015, 139, 1-16. [CrossRef] 
56. Łapczyński, M. Drzewa Klasyfikacyjne i Regresyjne w Badaniach Marketingowych; Wydawnictwo Uniwersytetu Ekonomicznego w Krakowie: Kraków, Poland, 2010.

57. Sroka, W.; Dacko, M. Ocena czynników rozwoju przodujących gospodarstw rolniczych z wykorzystaniem metody drzew regresyjnych typu C\&RT. ZagadnieniaEkon. Rolnej 2010, 2, 100-112.

58. Breiman, L.; Friedman, J.H.; Olshen, R.A.; Stone, C.J. Classification and Regression Trees; Wadsworth \& Brooks: Monterey, CA, USA, 1984.

59. Jarosik, V. CART and related methods. In Encyclopedia of Biological Invasions; Simberlo, D., Rejmánek, M., Eds.; University of California Press: Berkeley, CA, USA, 2011; pp. 104-108.

60. Ives, C.D.; Kendal, D. Values and attitudes of the urban public towards peri-urban agricultural land. Land Use Policy 2013, 34, 80-90. [CrossRef]

61. Sroka, W. Struktura oraz intensywność użytkowania gruntów rolnych w miastach i na obszarach podmiejskich. Rocz. Stowarzyszenia Ekon. Rol. Agrobiz. 2014, XVI, 449-455.

62. Czyżewski, A.; Gronowski, B.; Matuszczak, A. Gminy wiejskie i rolnictwo w aglomeracji poznańskiej po 2004 r. Probl. Drob. Gospod. Rol. 2017, 4, 49-61. [CrossRef]

63. Williams, F.; Farrington, J. Succession and the future of farming: Problem or perception. In Conference on the Rural Citizen: Governance, Culture and Wellbeing in the 21st Century; University of Plymouth: Plymouth, UK, 2006; pp. 1-7.

64. Brandth, B.; Overrein, G. Resourcing children in a changing rural context: Fathering and farm succession in two generations of farmers. Sociol. Rural. 2013, 53, 95-111. [CrossRef]

65. Zasada, I.; Loibl, W.; Köstl, M.; Piorr, A. Agriculture under human influence: A spatial analysis of farming systems and land use in European rural-urban-regions. Eur. Countrys. 2013, 5, 71-88. [CrossRef]

66. Vinogradovs, I.; Nikodemus, O.; Elferts, D.; Brumelis, G. Assessment of site-specific drivers of farmland abandonment in mosaic-type landscapes: A case study in Vidzeme, Latvia. Agric. Ecosyst. Environ. 2018, 253, 113-121. [CrossRef]

67. Paül, V.; Tonts, M. Containing urban sprawl: Trends in land use and spatial planning in the metropolitan region of Barcelona. J. Environ. Plan. Manag. 2005, 48, 7-35. [CrossRef]

68. Zasada, I.; Fertner, C.; Piorr, A.; Nielsen, T.S. Peri-urbanisation and multifunctional adaptation of agriculture around Copenhagen. Geogr. Tidsskr.-Dan. J. Geogr. 2011, 111, 59-72. [CrossRef]

69. Sroka, W.; Wass, A.; Pölling, B. Development Strategies of Urban Farms in Developed Countries on the Example of Ruhr Metropolis (Germany) and Upper Silesia Metropolis (Poland). Probl. Agric. Econ. 2016, 3, 65-88.

70. Kerbler, B. Factors affecting farm succession: The case of Slovenia. Agric. Econ. 2012, 58, 285-298. [CrossRef]

71. Alonso, W. Location and Land Use; Harvard University Press: Cambridge, MA, USA, 1964.

72. Deng, X.; Huang, J.; Rozelle, S.; Zhang, J.; Li, Z. Impact of urbanization on cultivated land changes in China. Land Use Policy 2015, 45, 1-7. [CrossRef]

73. Bika, Z. The territorial impact of the farmers' early retirement scheme. Sociol. Rural. 2007, 47, $246-272$. [CrossRef]

74. Chaplin, H.; Davidova, S.; Gorton, M. Agricultural adjustment and the diversification of farm households and corporate farms in Central Europe. J. Rural Stud. 2004, 20, 61-77. [CrossRef]

(C) 2019 by the authors. Licensee MDPI, Basel, Switzerland. This article is an open access article distributed under the terms and conditions of the Creative Commons Attribution (CC BY) license (http://creativecommons.org/licenses/by/4.0/). 